OPEN ACCESS

Edited by:

Maria De Lourdes Pereira, University of Aveiro, Portugal

Reviewed by: Juan Carlos Sepúlveda-Arias, Technological University of Pereira,

Colombia

Francis-Alfred Unuagbe Attah,

University of llorin, Nigeria Mahaveer Dhobi,

Delhi Pharmaceutical Sciences and

Research University, India

*Correspondence: Sitesh C. Bachar

bacharsc@du.ac.bd Kishor Mazumder kmazumder@just.edu.bd

Specialty section: This article was submitted to Ethnopharmacology,

a section of the journal

Frontiers in Pharmacology

Received: 29 June 2021 Accepted: 22 October 2021 Published: 08 November 2021

Citation:

Bachar SC, Mazumder K, Bachar R, Aktar A and Al Mahtab M (2021) A Review of Medicinal Plants with Antiviral Activity Available in Bangladesh and Mechanistic Insight Into Their Bioactive Metabolites on

SARS-CoV-2, HIV and HBV.

Front. Pharmacol. 12:732891. doi: 10.3389/fphar.2021.732891

\section{A Review of Medicinal Plants with Antiviral Activity Available in Bangladesh and Mechanistic Insight Into Their Bioactive Metabolites on SARS-CoV-2, HIV and HBV}

\author{
Sitesh C. Bachar ${ }^{1 *}$, Kishor Mazumder ${ }^{2,3,4 *}$, Ritesh Bachar ${ }^{5}$, Asma Aktar $^{2}$ and \\ Mamun Al Mahtab ${ }^{6}$
}

${ }^{1}$ Department of Pharmacy, Faculty of Pharmacy, University of Dhaka, Dhaka, Bangladesh, ${ }^{2}$ Department of Pharmacy, Jashore University of Science and Technology, Jashore, Bangladesh, ${ }^{3}$ School of Optometry and Vision Science, UNSW Medicine, University of New South Wales (UNSW), Sydney, NSW, Australia, ${ }^{4}$ School of Biomedical Sciences and Graham Centre for Agricultural Innovation, Charles Sturt University, Wagga, NSW, Australia, ${ }^{5}$ Department of Pharmacy, School of Science and Engineering, University of Information Technology and Sciences, Dhaka, Bangladesh, ${ }^{6}$ Department of Hepatology, Bangabandhu Sheikh Mujib Medical University, Dhaka, Bangladesh

Currently, viral infection is the most serious health issue which causing unexpected higher rate of death globally. Many viruses are not yet curable, such as corona virus-2 (SARSCoV-2), human immunodeficiency virus (HIV), hepatitis virus, human papilloma virus and so others. Furthermore, the toxicities and ineffective responses to resistant strains of synthetic antiviral drugs have reinforced the search of effective and alternative treatment options, such as plant-derived antiviral drug molecules. Therefore, in the present review, an attempt has been taken to summarize the medicinal plants reported for exhibiting antiviral activities available in Bangladesh along with discussing the mechanistic insights into their bioactive components against three most hazardous viruses, namely SARS-CoV-2, HIV, and HBV. The review covers 46 medicinal plants with antiviral activity from 25 families. Among the reported 79 bioactive compounds having antiviral activities isolated from these plants, about 37 of them have been reported for significant activities against varieties of viruses. Hesperidin, apigenin, luteolin, seselin, 6-gingerol, humulene epoxide, quercetin, kaempferol, curcumin, and epigallocatechin-3-gallate (EGCG) have been reported to inhibit multiple molecular targets of SARS-CoV-2 viral replication in a number of in silico investigations. Besides, numerous in silico, in vitro, and in vivo bioassays have been demonstrated that EGCG, anolignan-A, and B, ajoene, curcumin, and oleanolic acid exhibit anti-HIV activity while piperine, ursolic acid, oleanolic acid, (+)-cycloolivil-4'-O- $\beta-d-$ glucopyranoside, quercetin, EGCG, kaempferol, aloin, apigenin, rosmarinic acid, andrographolide, and hesperidin possess anti-HBV activity. Thus, the antiviral medicinal plants and the isolated bioactive compounds may be considered for further advanced investigations with the aim of the development of effective and affordable antiviral drugs.

Keywords: antiviral drug discovery, medicinal plants, viral diseases, natural antiviral, SARS-CoV-2 


\section{INTRODUCTION}

Currently, viral infection has come to be the major global challenge to healthcare professionals due to uncontrolled rate of morbidity as well as mortality. A number of life-threatening viruses including human immunodeficiency virus (HIV), hepatitis virus subtype $\mathrm{A}, \mathrm{B}$, and $\mathrm{C}(\mathrm{HAV}, \mathrm{HBV}$, and $\mathrm{HCV})$, herpes simplex virus (HSV), influenza virus, and so others have been affected human health for decades. Along with these preexisting viruses, corona virus-2 (SARS-CoV-2) has been turning into a global burden from 2019. The corona virus infection, also termed as "the novel coronavirus disease" (COVID-19) is characterized by severe acute respiratory syndrome resulting very high rate of death (Gisondi et al., 2020). Unfortunately, lack of safe as well as effective antiviral drugs against these viruses has worsened the situation.

Over past few decades, advanced scientific research has discovered many synthetic antiviral agents which are effective against many of the viral infectious diseases. Unfortunately, these synthetic drugs have been reported to produce countless adverse effects. In some cases, they may become ineffective on emerging viral resistant strains (Kurokawa et al., 2010). Along with this, the population in developing countries can't afford these expensive synthetic medicines for treatment of viral diseases. Keeping in view the global burden of viral infections as well as medication cost, there is an urgent need to develop new strategies to search for affordable and effective antiviral drugs.

Ethnopharmacology has contributed immensely to the development of phytotherapeutics and the discovery of new drugs (Heinrich and Gibbons, 2001). In recent time, medicinal plants and their bioactive metabolites have become one of the main focuses of interest to search for effective as well as affordable drugs to cope with the current necessities (Perera and Efferth, 2012). Traditional herbal medicine from indigenous origin has an ancient history of curing numerous chronic and infective diseases. Hence, the quest for novel antiviral agents focuses not only on synthetic combinations but also on the plantderived metabolites. A variety of plant metabolites can impede viral replication without affecting the host physiology or with limited side effects (Martin and Ernst, 2003; Hussain et al., 2017). Along with direct interferences to viral replication process, these natural products may exhibit potentiality to modulate the immune responses of host against viral infections (Kurokawa et al., 2010). Researchers have reported that numerous medicinal plants with antiviral activities, such as Andrographis paniculata, Lindera chunii, Dioscorea bulbifera, Wistaria floribunda, Xanthoceras sorbifoli, and Aegle marmelos showed remarkable anti-HIV activity (Kaur et al., 2020). Moreover, a number of natural or plant-derived compounds belonging to different chemical groups have been reported for their potential antiHBV activities (Chou et al., 2012; Qiu and Chen, 2013; Parvez et al., 2016; Wu, 2016). Some plant products have shown similar or even better efficacy against this virus than that of interferons and/or lamivudine treatment (Chen and Zhu, 2013; Arbab et al., 2017; Zhang et al., 2017). Interestingly, therefore, approximately
$80 \%$ of the chronic hepatitis B (CHB) patients in China rely on traditional herbal medicines.

There is much to gain and learn about remedial qualities of plants from the pre-existing knowledge of traditional medicines that may be evaluated for various applications as potential antiviral drugs. It is convenient to find plants that can be researched upon; however, what is required is the traditional knowledge that must be translated into pharmaceutical application in formulating novel drugs, finally taking it from the laboratory bench to the bedside. Even though numerous medicinal plants as well as plant derived metabolites have been reported for their antiviral effects, there lacks adequate combined substantial reports of pre-existing researches with mechanistic insights (Martin and Ernst, 2003). In most of the cases, due to lack of any substantial compilation report, the researchers conducted the similar studies as preliminary screening prior to design the advanced stages of discovery of potent drug molecule from plant. This is a complete loss of time, money and efforts. Therefore, an attempt is taken to review the medicinal plants indigenous to and/or cultivated in Bangladesh having antiviral activities along with emphasizing mechanistic insights of their bioactive metabolites on viral replication cycles of the most hazardous viruses, like SARS-CoV-2, HIV, and HBV with the hope of supporting the discovery of new and alternative antiviral drugs.

\section{METHOD}

\section{Search Scheme}

Renowned and globally accepted scientific databases including Google scholar (https://scholar.google.com/), PubMed (https:// pubmed.ncbi.nlm.nih.gov/), ScienceDirect (http://www. sciencedirect.com/), Scopus (http://www.scopus.com/), Springer Link (http://link.springer.com/), and Wiley Online Library (http://onlinelibrary.wiley.com/) were accessed to search literatures by emphasizing specific terminologies, such as "antiviral," "medicinal plants," "Bangladesh," "Indian subcontinent," "bioactive compounds," "structure activity relationship," and "antiviral mechanism". Only literatures written in English language were considered due to language barrier.

\section{Inclusion Criteria and Data Extraction}

In this review, studies covering following types of data were included and extracted: medicinal plants with antiviral activity along with their distribution, availability, traditional and folklore use, in vitro and in vivo studies of plant extracts and isolated bioactive compounds, their structural activity relationship and mechanism of antiviral activities. The focus of this review was on potential antiviral metabolites indigenous to and cultivated in Bangladesh. Due to lack of adequate scientific data regarding antiviral activities of medicinal plants collected from Bangladesh, available studies conducted on similar plant species in different countries are considered. 
TABLE 1 | Overview of the effects of medicinal plants extracts on common viral infections.

\begin{tabular}{|c|c|c|c|c|c|c|}
\hline Family & Species & Extract type & Part used & Bioactive compound & Antiviral activity & References \\
\hline \multirow[t]{3}{*}{ Acanthaceae } & Acanthus ilicifolius L. & $\begin{array}{l}\text { Alcoholic } \\
\text { extract }\end{array}$ & Whole plant & - & HBV & Wei et al. (2015) \\
\hline & $\begin{array}{l}\text { Andrographis } \\
\text { paniculata (Burm.f.) } \\
\text { Nees }\end{array}$ & EE & Leaf & Andrographolide & HSV-I, HIV, and EBV & Jayakumar et al. (2013) \\
\hline & Justicia adhatoda L. & $\mathrm{ME}$ & Leaf & Anisotine & $\begin{array}{l}\text { SARS-CoV-2, influenza } \\
\text { virus, and HSV }\end{array}$ & $\begin{array}{l}\text { Chavan and Chowdhary } \\
\text { (2014); Ghosh et al. (2021 }\end{array}$ \\
\hline Amaranthaceae & $\begin{array}{l}\text { Achyranthes } \\
\text { aspera } L .\end{array}$ & $\mathrm{ME}$ & Leaf & Oleanolic acid & HSV-I and II & Mukherjee et al. (2013) \\
\hline Amaryllidaceae & Allium sativum L. & $\begin{array}{l}\text { AE, ME, EE, and } \\
\text { n-hexane } \\
\text { extract, and } \\
\text { garlic oil }\end{array}$ & Bulb & $\begin{array}{l}\text { Ajoene, allicin, alliin, allyl methyl } \\
\text { thiosulfinate, methyl allyl } \\
\text { thiosulfinat, allitridin, diallyl sulfide, } \\
\text { garlicin, and lectin }\end{array}$ & $\begin{array}{l}\text { ADV-3, ADV-41, DENV, } \\
\text { SARS-CoV-2, HSV-I and } \\
\text { II, HCMV, H9N2, IBV, } \\
\text { H1N1, CBV-3, ECHO, } \\
\text { EV-71, HRV-2, HAV, } \\
\text { MeV, PIV-3, W, VSV, } \\
\text { HIV-1, REV }\end{array}$ & Rouf et al. (2020) \\
\hline Anacardiaceae & Mangifera indica L & $\mathrm{AE}$ & Fruit & Mangiferin & $\begin{array}{l}\text { Human influenza virus, } \\
\text { HSV-I, and HIV }\end{array}$ & Al-Rawi et al. (2019) \\
\hline \multirow[t]{2}{*}{ Apocynaceae } & $\begin{array}{l}\text { Alstonia scholaris (L.) } \\
\text { R. Br. }\end{array}$ & $\begin{array}{l}\text { EE fraction of } \\
\text { total alkaloid }\end{array}$ & Leaf & Total alkaloid & $\mathrm{IAV}$ & Zhou et al. (2020) \\
\hline & $\begin{array}{l}\text { Calotropis gigantea } \\
\text { (L.) Dryand. }\end{array}$ & - & Latex & $\begin{array}{l}\text { (+)-pinoresinol 4-O- }\left(6^{\prime \prime} \text { - }\right. \\
\text { O-vanilloyl)- } \beta \text {-D-glucopyranoside } \\
6^{\prime} \text {-O-vanilloyltachioside } 66^{\prime}-O \text { - } \\
\text { vanilloyl-isotachioside }\end{array}$ & Influenza $\left(\mathrm{H}_{1} \mathrm{~N}_{1}\right)$ & Parhira et al. (2014) \\
\hline Asphodelaceae & Aloe vera (L.) Burm.f. & $\mathrm{EE}$ & Leaf & $\begin{array}{l}\text { Feralolide, 9-dihydroxyl-2-O-(z)- } \\
\text { cinnamoyl-7-methoxy-aloesin, } \\
\text { aloeresin, quercetin, catechin } \\
\text { hydrate, and kaempferol }\end{array}$ & $\begin{array}{l}\text { SARS-CoV-2, and } \\
\text { influenza virus }\left(\mathrm{H}_{1} \mathrm{~N}_{1} \text { or }\right. \\
\left.\mathrm{H}_{3} \mathrm{~N}_{2}\right)\end{array}$ & $\begin{array}{l}\text { Choi et al. (2019); Mpiana } \\
\text { et al. (2020) }\end{array}$ \\
\hline
\end{tabular}

\begin{tabular}{|c|c|c|c|c|c|c|}
\hline Asteraceae & Eclipta prostrata L. & $\mathrm{ME}$ & Leaf & Coumestan & $\mathrm{HCV}$ & Kaushik-Basu et al. (2008) \\
\hline Bombacaceae & Bombax ceiba $L$. & EE & Flower & $\begin{array}{c}\text { Kaempferol-3-O-(6" }-O-E \text { - } \\
\text { p-coumaroyl)- } \\
\beta \text {-D-glucopyranoside }\end{array}$ & RSV, and SARS-CoV-2 & $\begin{array}{l}\text { Schwarz et al. (2014); } \\
\text { Zhang et al. (2015) }\end{array}$ \\
\hline
\end{tabular}

\begin{tabular}{|c|c|c|c|c|c|c|}
\hline Combretaceae & $\begin{array}{l}\text { Anogeissus } \\
\text { acuminata (Roxb. ex } \\
\text { DC.) Wall. ex Guillem. } \\
\text { \& Perr }\end{array}$ & - & - & Anolignan A Anolignan B & HIV & El-Ansari et al. (2020) \\
\hline Cyperaceae & Cyperus rotundus L. & Essential oil & Rhizome & $\begin{array}{l}\text { Humulene epoxide, and } \\
\text { caryophyllene oxide }\end{array}$ & $\begin{array}{l}\text { SARS-CoV-2, HAV, } \\
\text { HSV-I, and CVB }\end{array}$ & $\begin{array}{l}\text { Samra et al. (2020); Amparo } \\
\text { et al. (2021) }\end{array}$ \\
\hline \multirow[t]{2}{*}{ Fabaceae } & $\begin{array}{l}\text { Albizia procera (Roxb.) } \\
\text { Benth. }\end{array}$ & $E E$, and $E A E$ & Bark & $\begin{array}{l}(+) \text {-catechin, and protocatechuic } \\
\text { acid }\end{array}$ & IAV & Panthong et al. (2015) \\
\hline & $\begin{array}{l}\text { Butea monosperma } \\
\text { (Lam.) Taub. }\end{array}$ & $\mathrm{AE}$ & $\begin{array}{l}\text { Bark, } \\
\text { flower, fruit, } \\
\text { leaf, and } \\
\text { root }\end{array}$ & $\begin{array}{l}\text { 5,7-dihydroxy -3,6,4-trimethoxy } \\
\text { flavone-7-O- } \alpha-L \text { xylopyranosyl } \\
(1 \rightarrow 3)-O-\alpha-L \text { arabinopyranosyl- } \\
(1 \rightarrow 4)-O-\beta-D \text { galactopyranoside }\end{array}$ & EV-71 & $\begin{array}{l}\text { Panda et al. (2017); Tiwari } \\
\text { et al. (2019) }\end{array}$ \\
\hline Flacourtiaceae & $\begin{array}{l}\text { Flacourtia indica } \\
\text { (Burm.f.) Merr. }\end{array}$ & EAE & Stem bark & $\begin{array}{l}\text { Flacourtosides } A \text { and } E \text {, betulinic } \\
\text { acid } 3 \beta \text {-caffeate, and } \\
\text { scolochinenoside D }\end{array}$ & DENV, and CHIKV & Bourjot et al. (2012) \\
\hline Gentianaceae & $\begin{array}{l}\text { Swertia angustifolia } \\
\text { var. pulchella (D. Don) } \\
\text { Burkill }\end{array}$ & - & Whole plant & $\begin{array}{l}\text { (+)-cycloolivil-4'-O- } \beta-d- \\
\text { glucopyranoside, } \\
\text { swertiachiralatone } A\end{array}$ & HBV, and HSV-I & $\begin{array}{l}\text { Verma et al. (2008); Zhou } \\
\text { et al. (2015) }\end{array}$ \\
\hline
\end{tabular}


TABLE 1 | (Continued) Overview of the effects of medicinal plants extracts on common viral infections.

\begin{tabular}{|c|c|c|c|c|c|c|}
\hline Family & Species & Extract type & Part used & Bioactive compound & Antiviral activity & References \\
\hline \multirow[t]{8}{*}{ Lamiaceae } & $\begin{array}{l}\text { Ocimum } \\
\text { tenuiflorum L. }\end{array}$ & $A E$, and $E E$ & Aerial part & $\begin{array}{l}\text { Ursolic acid, Eugenol, 1,8- cineole } \\
\text { and, rosmarinic acid }\end{array}$ & HSV-I, and II & $\begin{array}{l}\text { Caamal-Herrera et al. } \\
(2016)\end{array}$ \\
\hline & Ocimum basilicum L. & $\mathrm{ME}$, and $\mathrm{EE}$ & Aerial part & $\begin{array}{l}\text { 1,8-cineole, camphor, thymol, } \\
\text { eugenol, eugenol epoxide, } \\
\text { apigenin, linalool, and ursolic acid }\end{array}$ & $\begin{array}{l}\text { HIV-I, HSV, ADV-3, 8, 11, } \\
\text { HVB, EV, and CVB-I }\end{array}$ & $\begin{array}{l}\text { Behbahani et al. (2013); } \\
\text { Kubiça et al. (2014); } \\
\text { Tshilanda et al. (2020) }\end{array}$ \\
\hline & $\begin{array}{l}\text { Ocimum } \\
\text { gratissimum L. }\end{array}$ & Essential oil & Leaf & Eugenol, and thymol & HSV-I, and II & $\begin{array}{l}\text { Maria das Graças et al. } \\
\text { (2007); Benencia and } \\
\text { Courreges (2000); Benitez } \\
\text { et al. (2009); Lai et al. (2012) }\end{array}$ \\
\hline & $\begin{array}{l}\text { Ocimum } \\
\text { campechianum Mill. }\end{array}$ & $\begin{array}{l}\text { Essential oil, } \\
\text { and } A E\end{array}$ & $\begin{array}{l}\text { Leaf, Aerial } \\
\text { part }\end{array}$ & $\beta$-caryophyllene, and 1,8-cineole & HSV-I, II, and IBV & $\begin{array}{l}\text { Maria das Graças et al. } \\
\text { (2007); Astani et al. (2010); } \\
\text { Yang et al. (2010); } \\
\text { Tshilanda et al. (2020) }\end{array}$ \\
\hline & $\begin{array}{l}\text { Ocimum } \\
\text { americanum L. }\end{array}$ & $\mathrm{ME}$, and $\mathrm{DE}$ & Leaf & Rosmarinic, and oleanolic acid & EV-71, and HIV-I & $\begin{array}{l}\text { Aluko et al. (2012); Chung } \\
\text { et al. (2015); Pandey et al. } \\
\text { (2017); Tshilanda et al. } \\
\text { (2019) }\end{array}$ \\
\hline & $\begin{array}{l}\text { Ocimum } \times \text { africanum } \\
\text { Lour. }\end{array}$ & $\mathrm{EE}$ & $\begin{array}{l}\text { Leaf, aerial } \\
\text { part }\end{array}$ & Caffeic acid, and linalool & HSV-I, and ADV-11 & $\begin{array}{l}\text { Romeilah et al. (2010); } \\
\text { Ikeda et al. (2011); Pandey } \\
\text { et al. (2017) }\end{array}$ \\
\hline & $\begin{array}{l}\text { Ocimum forsskaolii } \\
\text { Benth. }\end{array}$ & $\mathrm{EE}$ & Leaf & Ursolic acid & $\mathrm{HCV}$ & Silva et al. (2008) \\
\hline & $\begin{array}{l}\text { Ocimum carnosum } \\
\text { (Spreng.) Link \& Otto } \\
\text { ex Benth. }\end{array}$ & Essential oil & Leaf & Trans-anethole & HSV-I, and II & Astani et al. (2010) \\
\hline \multirow[t]{2}{*}{ Meliaceae } & $\begin{array}{l}\text { Azadirachta indica } \\
\text { A.Juss. }\end{array}$ & $\mathrm{AE}$ & $\begin{array}{l}\text { Bark and } \\
\text { leaf }\end{array}$ & $\begin{array}{l}\text { Gedunin, pongamol, and } \\
\text { azadirachtin }\end{array}$ & $\begin{array}{l}\text { HSV-I, CVB-B4, HBV, } \\
\text { and SARS-CoV-2 }\end{array}$ & $\begin{array}{l}\text { Alzohairy (2016); Rao and } \\
\text { Yeturu (2020); Nesari et al. } \\
\text { (2021) }\end{array}$ \\
\hline & Melia azedarach L. & $\mathrm{EAE}$ & Leaf & $\begin{array}{l}\text { Limonoid 1-cinnamoyl-3,11- } \\
\text { dihydroxymeliacarpin }\end{array}$ & VSV, and HSV-I & Alché et al. (2003) \\
\hline \multirow[t]{5}{*}{ Moraceae } & Ficus religiosa L. & $\begin{array}{l}\mathrm{ME}, \mathrm{AE}, \text { and } \\
\text { chloroform } \\
\text { extracts }\end{array}$ & Bark & - & RSV, HRV, and HSV-II & $\begin{array}{l}\text { Cagno et al. (2015); Ghosh } \\
\text { et al. (2016) }\end{array}$ \\
\hline & $\begin{array}{l}\text { Artocarpus integer } \\
\text { (Thunb.) Merr. }\end{array}$ & $\mathrm{AE}$ & Bark & - & Rotavirus & Gonçalves et al. (2005) \\
\hline & $\begin{array}{l}\text { Artocarpus } \\
\text { heterophyllus Lam. }\end{array}$ & $\mathrm{DE}$ & Leaf & - & $\mathrm{HCV}$ & Hafid et al. (2017) \\
\hline & $\begin{array}{l}\text { Artocarpus camansi } \\
\text { Blanco }\end{array}$ & $\mathrm{DE}$ & Leaf & - & $\mathrm{HCV}$ & Hafid et al. (2017) \\
\hline & $\begin{array}{l}\text { Artocarpus altilis } \\
\text { (Parkinson ex } \\
\text { F.A.Zorn) Fosberg }\end{array}$ & $\mathrm{DE}$ & Leaf & - & $\mathrm{HCV}$ & Hafid et al. (2017) \\
\hline Phyllanthaceae & Phyllanthus niruri L. & $\mathrm{AE}$, and $\mathrm{EE}$ & Whole plant & Phyllanthin, and hypophyllantin & $\mathrm{HBV}, \mathrm{WHV}$, and HCV & $\begin{array}{l}\text { Tan et al. (2013); Wahyuni } \\
\text { et al. (2019) }\end{array}$ \\
\hline \multirow[t]{2}{*}{ Piperaceae } & Piper longum L. & $\mathrm{EE}$ & Seed & Piperine & VSV-IN, PIV, and HBV & $\begin{array}{l}\text { Jiang et al. (2013); Priya and } \\
\text { Saravana Kumari (2017) }\end{array}$ \\
\hline & Piper nigrum L. & - & Seed & Guaiol & $\begin{array}{l}\text { VSV-IN, PIV, and SARS- } \\
\text { CoV-2 }\end{array}$ & $\begin{array}{l}\text { Pandey et al. (2021) Priya } \\
\text { and Saravana Kumari } \\
\text { (2017) }\end{array}$ \\
\hline Poaceae & Cynodon dactylon L. & - & Whole plant & - & $\mathrm{BCoV}$ & Nalanagula, (2020) \\
\hline Rosaceae & Rosa centifolia L. & $\mathrm{ME}$ & Leaf & - & HIV & Palshetkar et al. (2020) \\
\hline Rubiaceae & $\begin{array}{l}\text { Hedyotis scandens } \\
\text { Roxb. }\end{array}$ & $\mathrm{EE}$ & Whole plant & $\begin{array}{l}\text { Maltol } 60-\text { b-D-apiofuranosyl-b-D- } \\
\text { gluco-pyranoside, and } \\
\text { grevilloside G }\end{array}$ & RSV & Wang et al. (2013) \\
\hline
\end{tabular}


TABLE 1 | (Continued) Overview of the effects of medicinal plants extracts on common viral infections.

\begin{tabular}{|c|c|c|c|c|c|c|}
\hline Family & Species & Extract type & Part used & Bioactive compound & Antiviral activity & References \\
\hline \multirow[t]{4}{*}{ Rutaceae } & $\begin{array}{l}\text { Aegle marmelos (L.) } \\
\text { Corrêa }\end{array}$ & - & - & Seselin & SARS-CoV-2 & Nivetha et al. (2021) \\
\hline & $\begin{array}{l}\text { Citrus limon (L.) } \\
\text { Osbeck }\end{array}$ & Essential oil & Fruit & Luteolin & HAV & Battistini et al. (2019) \\
\hline & $\begin{array}{l}\text { Citrus sinensis (L.) } \\
\text { Osbeck }\end{array}$ & Essential oil & Fruit & Hesperidin, luteolin, and vitamin C & HAV, and SARS-CoV-2 & $\begin{array}{l}\text { Battistini et al. (2019); } \\
\text { Bellavite and Donzelli (2020) }\end{array}$ \\
\hline & $\begin{array}{l}\text { Citrus paradisi } \\
\text { Macfad. }\end{array}$ & Essential oil & Fruit & - & HAV & Battistini et al. (2019) \\
\hline Theaceae & $\begin{array}{l}\text { Camellia sinensis (L.) } \\
\text { Kuntze }\end{array}$ & - & Leaf & $\begin{array}{l}\text { Epigallocatechin-3-gallate } \\
\text { (EGCG), epicatechin gallate } \\
\text { (ECG), epicatechin (EC), and } \\
\text { catechin }\end{array}$ & $\begin{array}{l}\text { HIV, HSV-I, IAV, HCV, } \\
\text { HBV, VSV, reovirus, } \\
\text { mCMV, DENV, JEV, } \\
\text { CHIKV, ZIKV, TBEV, } \\
\text { EV71, and rotavirus }\end{array}$ & Xu et al. (2017) \\
\hline Urticaceae & Boehmeria nivea L. & EE & Root & - & $\mathrm{HBV}$ & Chang et al. (2010) \\
\hline \multirow[t]{2}{*}{ Zingiberaceae } & $\begin{array}{l}\text { Zingiber officinale } \\
\text { Roscoe }\end{array}$ & $\mathrm{AE}$ & Rhizome & 6-gingerol, and gingeronone A & $\begin{array}{l}\text { CHIKV, HCV, and SARS- } \\
\text { CoV-2 }\end{array}$ & $\begin{array}{l}\text { Pandey et al. (2021); Abd } \\
\text { El-Wahab et al. (2009); } \\
\text { Kaushik et al. (2020); } \\
\text { Rathinavel et al. (2020) }\end{array}$ \\
\hline & Curcuma longa L. & $\mathrm{AE}$ & Rhizome & Curcumin & $\begin{array}{l}\text { HBV, SARS-CoV-2, HIV, } \\
\text { IAV, DENV, CHIKV, VSV, } \\
\text { ZIKV, Kaposi sarcoma- } \\
\text { associated HSV, } \\
\text { and RSV }\end{array}$ & $\begin{array}{l}\text { Kim et al. (2009); Jennings } \\
\text { and Parks (2020); } \\
\text { Thimmulappa et al. (2021) }\end{array}$ \\
\hline
\end{tabular}

- indicates not found; $A E$, aqueous extract; $M E$, methanolic extract; $E E$, ethanolic extract; DE, dichloromethane extract, and EAE, ethyl acetate extract.

\begin{tabular}{|c|c|c|c|c|c|}
\hline Intervention & Phase & Indication & Primary purpose & Study place & References \\
\hline Andrographolide & IV & Acute Bronchitis & Treatment & China & https://clinicaltrials.gov/ct2/show/NCT03132623 \\
\hline Quercetin & $\mathrm{N} / \mathrm{A}$ & COVID-19 & Prevention & Turkey & https://clinicaltrials.gov/ct2/show/NCT04377789 \\
\hline Hesperidin & $\|$ & COVID-19 & Treatment & Canada & https://clinicaltrials.gov/ct2/show/NCT04715932 \\
\hline Curcumin & $\mathrm{N} / \mathrm{A}$ & COVID-19 & Prophylaxis & India & $\begin{array}{l}\text { http://www.ctri.nic.in/Clinicaltrials/pdf_generate.php? } \\
\text { trialid=45936\&EncHid=\&modid=\&compid=\%27, } \\
\% 2745936 \text { det } \% 27\end{array}$ \\
\hline
\end{tabular}

\section{ANTIVIRAL PLANTS OF BANGLADESH}

In this review, we have discussed the antiviral activities of medicinal plants indigenous to and/or cultivated in Bangladesh along with their phytocompounds and the corresponding mechanisms of antiviral activity. A total of 46 antiviral plants from 25 families were substantiated in Table 1. According to families, medicinal plants were categorized. About 36 bioactive metabolites with significant effects and their underlying mechanisms of these antiviral activities were summarized in Table 3.

\section{Acanthaceae}

Acanthus ilicifolius L. belonging to family Acanthaceae, is a mangrove plant with numerous medicinal properties, including anti-inflammatory, antioxidant and hepatoprotective activities. This medicinal plant exhibits potent antiviral activity against hepatitis B virus. A study performed on duck model revealed that alcoholic extract of whole plant is capable of reducing the viral load by interfering DNA replication, but the exact mechanism was not explained well (Wei et al., 2015). Andrographis paniculata (Burm.f.) Nees belongs to Acanthaceae family as well. It possesses excellent neutralizing activity against the human immunodeficiency virus (HIV). Andrographolide is a phytochemical isolated from this plant which has been reported for antiviral activity against herpes simplex virus (HSV), HIV, flaviviruses, and pestiviruses (Jayakumar et al., 2013). This compound inhibited HIVinduced cell cycle dysregulation which results the increase of $\mathrm{CD}^{+}$lymphocyte levels in HIV-1 infected people (Calabrese et al., 2000). Besides, this bioactive compound has been reported for inhibition of the expressions of HSV-I viral envelope 
glycoproteins D and C (Wiart et al., 2005). Another study revealed that ethanolic extract $(25 \mu \mathrm{g} / \mathrm{ml})$ of $A$. paniculata as well as andrographolide $(5 \mu \mathrm{g} / \mathrm{ml})$ remarkably inhibited the expression of Epstein-Barr virus (EBV) lytic proteins, Rta, Zta, and EA-D in the viral lytic cycle in P3HR1 cells (Lin et al., 2008). This study has also demonstrated that andrographolide is nottoxic to P3HR1 cells at a dose of $<5 \mu \mathrm{g} / \mathrm{ml}$. This compound is now under clinical trial (phase-IV) for treatment of bronchitis (Table 2).

Justicia adhatoda L. is another member of Acanthaceae family which is native to Bangladesh. It is known as malabar nut, adhatoda or vasaka and traditionally used in cold, cough and respiratory disorders from ancient times. Methanolic extract of the leaves of this medicinal plant has been reported for inhibitory activities against influenza and herpes simplex virus (HSV). Six alkaloids namely vasicoline, vasicolinone, vasicinone, vasicine, adhatodine and anisotine have been isolated from the leaves of J. adhatoda. In silico bioassay demonstrated that anisotine has significantly inhibited the main protease (Mpro) of SARS-CoV-2. Mpro mediates the cleavage of polyprotein to get matured and acquire infectivity. The assay has also suggested that inhibitory potential of this alkaloid is higher compared to the inhibitory activities of lopinavir and darunavir (established antiviral drugs) (Ghosh et al., 2021).

\section{Amaranthaceae}

Achyranthes aspera L. belonging to the family Amaranthaceae, is a medicinal plant of the Garo tribe population in the Madhupur forest region of Bangladesh. It is a well-known folk medicine not only in Bangladesh but also in Indian subcontinent. It contains a potent antiviral compound named oleanolic acid which has been reported to work against herpes simplex virus type-I, HSV-I $\left(\begin{array}{ll}\mathrm{EC}_{50} & 6.8 \mu \mathrm{g} / \mathrm{ml})\end{array}\right)$ and type-II, HSV-2 $\left(\mathrm{EC}_{50} \quad 7.8 \mu \mathrm{g} / \mathrm{ml}\right)$ (Mukherjee et al., 2013). Both the plant extract and oleanolic acid inhibited the early stage of multiplication, specifically $2-6 \mathrm{~h}$ of post infection of the viruses.

\section{Amaryllidaceae}

Allium sativum L., a species of Amaryllidaceae family is considered as one of the rich sources of medicinal substances and has been used for healing infectious diseases like cold, flu, asthma and other viral infections from ancient time in traditional Chinese medicine, Islamic medicine and folklore. In Bangladesh, it is cultivated all over the country as a fundamental spice used in cooking. A study has been documented that various extracts of $A$. sativum have inhibitory activities against adenovirus-3 (ADV-3), adenovirus-41 (ADV-41) (Khanal et al., 2018), dengue virus (DENV) (Alejandria, 2015), SARS-CoV-2 (Rouf et al., 2020), HSV-I and II (Straface et al., 2012), human cytomegalovirus (HCMV), influenza $A$ virus (IAV) subtype $\mathrm{H}_{1} \mathrm{~N}_{1}$ and $\mathrm{H}_{9} \mathrm{~N}_{2}$, influenza B virus (IBV) (Mettenleiter and Sobrino, 2008), coxsackie $\mathrm{B}$ virus (CBV-3), echovirus-11 (ECHO), enterovirus (EV-71), human rhinovirus-2 (HRV-2), HAV, measles virus $(\mathrm{MeV})$, parainfluenza virus-3 (PIV-3), vaccinia virus (VV), vesicular stomatitis virus (VSV), HIV-1 (Wang et al., 2017), and reticuloendotheliosis virus (REV). Numerous antiviral phytocompounds have been isolated from a number of extracts of the bulb of $A$. sativum including ajoene, allicin, alliin, allyl methyl thiosulfinate, allitridin, diallyl sulfide, garlicin, and lectins. Ajoene prevents HIV-induced destruction of $\mathrm{CD}^{+}$cells and enhances cellular immunity. It also inhibits viral attachment to host cell and reverse transcriptase of HIV-I. Apart from these, it induces apoptosis of HCMV infected cells. Allicin and allyl methyl thiosulfinate inhibit the entry of HSV-I and II, PIV-3, VV, VSV and HRV-2 by disrupting viral envelope and cell membrane. Moreover, allicin inhibits the replication of REV by downregulation of ERK/MAPK pathway. Alliin, diallyl sulfide, and garlicin work against DENV by diminishing inflammation through suppressing oxidative stress. Allitridin has excellent multiple effects against HCMV. The underlying mechanisms of these activities include inhibition of viral DNA synthesis by interfering viral immediate-early antigen expression, inhibition of viral replication by suppressing viral IEG gene transcription, and enhancement of Treg expansion and Tregmediated anti-HCMV immunosuppression (Alejandria, 2015; Wang et al., 2017; Rouf et al., 2020).

\section{Anacardiaceae}

Mangifera indica L. is one of the most common plants for fruit considering as the king of all fruits in Bangladesh. It belongs to the family Anacardiaceae. This fruit is packed of antioxidants and other nutritious biomolecules. The plant extract has been reported for its activity against influenza virus. Apart from this, it contains a bioactive compound named mangiferin having potential efficacy for inhibiting the duplication of HSV-I and antagonizing the cytopathic effects of HIV (AlRawi et al., 2019).

\section{Apocynaceae}

Alstonia scholaris (L.) R. Br., a species of Apocynaceae family, is a folklore medicine in Bangladesh usually used to treat cold, cough, asthma, and chronic obstructive pulmonary disease (COPD). This plant is a rich source of total alkaloids having remarkable anti-inflammatory and antiviral activities. A study demonstrated that the total alkaloids present in this plant exhibited efficacy to fight against IAV. The mechanism of this antiviral activity involves inhibition of viral replication (in A549 cells and U937-derived macrophages), reduction of cytokine and chemokine generation at the mRNA and protein levels, as well as interfering the activation of pattern recognition receptor (PRR)- and IFN-activated signal transduction (in A549 cells). Along with these, increment of survival rate and reduction of the viral titer were observed in lethal PR8 mouse model (Zhou et al., 2020).

Another important species of Apocynaceae family is Calotropis gigantea (L.) Dryand., also known as milk weed which is found in Bandarban, Chattogram, Cox's Bazar, Khagrachari, and Rangamati of Bangladesh. From the latex of the plant, a lignan glycoside namely (+)-pinoresinol 4-O- $\left(6^{\prime \prime}-\mathrm{O}\right.$ vanilloyl)- $\beta$-d-glucopyranoside and two phenolic compounds such as $6^{\prime}$-O-vanilloyltachioside and $6^{\prime}$-Ovanilloylisotachioside have been isolated. Among them, the lignin glycoside was efficacious against $\mathrm{H}_{1} \mathrm{~N}_{1}$ strain of both of the subtypes $\mathrm{A}$ and $\mathrm{B}$ ( $\mathrm{IC}_{50}$ value of $\left.13.4-39.8 \mu \mathrm{g} / \mathrm{ml}\right)$. The 
demonstrated underlying mechanism of this activity involved inhibition of NF- $\kappa \mathrm{B}$ pathway and viral ribonucleoproteins nuclear exporting without interfering virus-induced activation of Raf/MEK/ERK pathway (Parhira et al., 2014).

\section{Asphodelaceae}

Aloe vera (L.) Burm.f. is a well-known medicinal plant belonging to Asphodelaceae family and found almost everywhere in Bangladesh. A. vera gel $(0.2-5 \%)$ has been reported for inhibitory activity on HSV-I growth in Vero cell line. This study has demonstrated that the gel is effective as topical treatment option for oral HSV-I infection (Rezazadeh et al., 2016). An in silico study revealed that treatment with ethanolic extract of $A$. vera significantly reduces of the replication of IAV along with inhibition of viral matrix protein 1 (M1), matrix protein 2 (M2), and hemagglutinin (HA) mRNA synthesis, and expressions of viral protein (M1, M2, and HA). Numerous potent antiviral bioactive compounds, such as quercetin, catechin hydrate, and kaempferol were isolated which have inhibited IAV (H1N1 or H3N2) induced autophagy, M2 viral mRNA synthesis, and M2 protein expression. Apart from these, in silico docking simulation study stated that these bioactive compounds have higher binding affinity (for M2 protein) compared to established M2 protein inhibitors (Choi et al., 2019). Recently, COVID-19 pandemic has created worldwide burden because of the unavailability of the suitable medical treatment option. Quercetin is under clinical trial for prophylaxis as well as management of the symptoms of this infection (Table 2). Furthermore, $A$. vera has been reported to contain 9-dihydroxyl-2-O-(z)-cinnamoyl-7-methoxy-aloesin, aloeresin and feralolide which showed potential to inhibit the main protease (3CLpro) responsible for the replication of SARSCoV-2 in an in silico investigation. This study also demonstrated that feralolide might be one of the foremost choices for development of potential drug for COVID-19 infection due to its higher binding affinity to 3CLpro, and drugability (according to the Lipinski's rule of five) (Mpiana et al., 2020).

\section{Asteraceae}

Eclipta prostrata L. is the only known member of Asteraceae family which has strong antiviral property. In Bangladesh, this valuable medicinal plant grows wildly in fallow lands and the cultivators consider them as weed. This plant is known as kalo keshi and used as folklore medicine to treat snake bite and blood borne hepatitis. Coumestan is a phytosterol found in this plant which has been reported for excellent inhibiting activity against NS5B protein of HCV. This protein is essential for viral RNA replication (Kaushik-Basu et al., 2008). Therefore, this compound and its analogs might be targeted for development of novel replication inhibitors of $\mathrm{HCV}$.

\section{Bombacaceae}

Bombax ceiba L., a member of Bombacaceae family, is very common plant in Bangladesh and found almost everywhere. It is also known as cotton tree because of producing cotton from flowers. Flower of this plant produces a flavonoid glycoside having a cis-coumaroyl connection, namely kaempferol-3-O-
(6" $6^{\prime \prime}-O$-E-p-coumaroyl)- $\beta$-D-glucopyranoside. This flavonoid glycoside has been reported for having inhibitory activity on respiratory syncytial virus (RSV) (Zhang et al., 2015). Besides, an in silico study stated that Kaempferol-3-O-(6"-O-E$p$-coumaroyl)- $\beta$-D-glucopyranoside inhibits the open-readingframe $3 \mathrm{a}$ (ORF 3a) protein of SARS-CoV-2. This protein is crucial for expression of a cation-selective channel which regulates viral release mechanism (Schwarz et al., 2014).

\section{Combretaceae}

Anogeissus acuminata (Roxb. ex DC.) Wall. ex Guillem. \& Perr. is an Asian species of Combretaceae family which is found in Bandarban, Chattogram, Cox's Bazar, Khagrachari and Rangamati area of Bangladesh. This plant produces two dibenzylbutadiene lignans, namely anolignan A and anolignan B which showed significant inhibitory activity against HIV-I reverse transcriptase (RT) enzyme. Besides, both of the phytocompounds exerted a synergistic activity against this enzyme (El-Ansari et al., 2020).

\section{Cyperaceae}

Cyperus rotundus L. belonging to family Cyperaceae, is considered as a troublesome and economically damaging weed found in almost all the croplands in Bangladesh. Surprisingly, this plant has numerous medicinal properties, including antidiarrheal, antioxidant, anti-inflammatory, antimutagenic, antiperiodic, anticonvulsant, anti-saturative, antipyretic, antifungal, antidiabetic, antimalarial, antilipidemic, antibacterial, antiviral, anti-tumoral, cardioprotective, and wound-healing properties (Peerzada et al., 2015). A study demonstrated that essential oil extracted from the rhizomes of this plant has inhibitory activity against HAV, HSV-I, and CVB. Humulene epoxide and caryophyllene oxide were identified as major bioactive compounds from this essential oil (Samra et al., 2020). Caryophyllene oxide has been reported to exhibit very potent inhibitory activity against HSV-I which might be a prime lead for development of topical therapeutic agent to treat recurrent infection caused by HSV-I (Astani et al., 2011). Moreover, an in silico study demonstrated that humulene epoxide has remarkable binding affinity to four target proteins, such as spike glycoprotein, papain-like protease (PLpro), 3chymotrypsin-like protease (3CLpro), and RNA-dependent RNA polymerase (RdRp) which are crucial for regulation of lifecycle of SARS-CoV-2 (Amparo et al., 2021).

\section{Fabaceae}

Albizia procera (Roxb.) Benth., a member of Fabaceae family is found in forests of Chittagong, Chittagong Hill Tracts, Cox's Bazar, and Dhaka-Mymensingh Sal forests of Bangladesh. It is very popular traditional medicinal plant whose bark (decoction) is used to manage rheumatism, hemorrhage, and stomach-ache (Sivakrishnan and Swamivelmanickam, 2019). This plant has potent antiviral activity against IAV. A study showed that ethanolic, ethyl acetate, aqueous and hexane-chloroform extracts of the bark of $A$. procera have inhibited the integrase enzyme of IVA with $\mathrm{IC}_{50}$ value of $19.5,19.1,21.3$, and $>100 \mu \mathrm{g} /$ $\mathrm{ml}$ respectively. Two major compounds such as $(+)$-catechin and 
protocatechuic acid have been isolated from the bark of this plant. $(+)$-Catechin showed substantial activity against IAV intergase ( IC $_{50}$ value: $46.3 \mu \mathrm{M}$ ), whereas the effect of protocatechuic acid was mild. In silico docking study suggested that (+)-catechin interacts with Thr66, Gly148, and Glu152 in the core domain of integrase enzyme, whereas protocatechuic acid binds to Thr66, His67, Glu152, Asn155, and Lys159 (Panthong et al., 2015).

Butea monosperma (Lam.) Taub., another important member of Fabaceae family, is a well-known medicinal plant found in almost everywhere in Bangladesh and known as flame of forest (local name: Palash). In Ayurvedic, Unani and Homeopathic medicine, this plant has numerous medicinal uses. However, scientific literature demonstrated that aqueous extract of various parts of this plant like bark, flowers, fruit, leaves, and roots showed significant inhibition of EV-71 (BrCr) (Panda et al., 2017). A flavone glycoside, namely 5,7-dihydroxy-3,6,4trimethoxy flavone-7-O- $\alpha-\mathrm{L}$ xylopyranosyl $(1 \rightarrow 3)-\mathrm{O}-\alpha-\mathrm{L}$ arabinopyranosyl- $(1 \rightarrow 4)-\mathrm{O}-\beta-\mathrm{D}$ galactopyranoside has been isolated form the flower of this plant which showed significant antiviral activity (Tiwari et al., 2019).

\section{Flacourtiaceae}

Flacourtia indica (Burm.f.) Merr. is a tropical species of family Flacourtiaceae with broad geographical distributions covering Bangladesh. It is an edible wild fruit species used by the traditional medical practitioners for treating snakebite. This medicinal plant has been reported for inhibitory activity against chikungunya (CHIKV) and dengue (DENV) viruses. Ethyl acetate extract of stem bark of this plant has inhibited CHIKV. Moreover, significant inhibitory activity has been observed against DENV RNA polymerase enzyme by the isolated compounds, such as flacourtosides $\mathrm{A}$ and $\mathrm{E}$, betulinic acid $3 \beta$-caffeate $\left(\mathrm{IC}_{50}=0.85 \pm 0.1 \mu \mathrm{M}\right)$, and scolochinenoside $\mathrm{D}$ ( IC $_{50}$ values $\sim 10 \mu \mathrm{M}$ ) (Bourjot et al., 2012).

\section{Gentianaceae}

Swertia angustifolia var. pulchella (D. Don) Burkill belonging to the family Gentianaceae, is a medicinal plant of Bangladesh which is mainly distributed in the mountainous regions. It is known as Ayurvedic herb and is usually used to treat malaria and diabetes. Besides, local populations use this herb as folklore medicine to manage hepatitis, inflammation, and digestive disorders. Crude extract of this herb has been reported for exhibiting activity against HSV-I (Verma et al., 2008). A novel bioactive compound named (+)-cycloolivil- $4^{\prime}-\mathrm{O}-\beta$-d-glucopyranoside has been isolated from this herb which inhibited $\mathrm{HBsAg}$ and $\mathrm{HBeAg}$ secretion ( $\mathrm{IC}_{50}$ values: $0.31 \pm 0.045 \mathrm{mM}$ and $0.77 \pm 0.076 \mathrm{mM}$ respectively) as well as $\mathrm{HBV}$ DNA replication ( $\mathrm{IC}_{50}$ value: $0.29 \pm$ $0.034 \mathrm{mM}$ ) in anti-HBV assay on HepG 2.2.15 cells line (Zhou et al., 2015).

\section{Lamiaceae}

The genus, Ocimum is a broad member of Lamiaceae family which are found everywhere in Bangladesh and known as "the medicinal herb for all disease". Species of this genus exhibit numerous medicinal properties and have been used from ancient time as folklore medicines. The genus is actually the biggest sources of antiviral phytocompounds (Tshilanda et al., 2020). About 8 species of this genus are found in Bangladesh, namely Ocimum tenuiflorum L., Ocimum basilicum L., Ocimum gratissimum L., Ocimum campechianum Mill., Ocimum americanum L., Ocimum $\times$ africanum Lour., Ocimum forsskaolii Benth., and Ocimum carnosum (Spreng.) Link \& Otto ex Benth. which have been reported extensively for diverse antiviral activities.

O. tenuiflorum is commonly known as "basil or holy basil" which is considered as holy plant according to Hinduism. This medicinal plant is found almost every yard of people in Bangladesh. It produces a number of antiviral bioactive compounds, such as ursolic acid, eugenol, 1,8-cineole, and rosmarinic acid which exhibit potential to inhibit HSV-I and II (Caamal-Herrera et al., 2016). O. basilicum, known as sweet basil, contains 1,8-cineole, camphor, thymol, eugenol, eugenol epoxide, apigenin, linalool, and ursolic acid which have been reported to work against HIV-I, HSV, ADV-3, 8, 11, HVB, EV, and CVB-I (Behbahani et al., 2013; Kubiça et al., 2014; Tshilanda et al., 2020). O. gratissimum is an aromatic herb which is commonly known as African basil. Essential oil of this basil leaves contains two alcohols namely eugenol and thymol. Eugenol inhibits replication of HSV-I and II while thymol destructs the virion of HSV-I (Benencia and Courreges, 2000; Maria das Graças et al., 2007; Benitez et al., 2009; Lai et al., 2012). $\beta$-caryophyllene and 1,8-cineole have been isolated from O. campechianum which exhibit anti-HSV-I and II activities as well as inhibit infectious bronchitis virus (IBV) (Maria das Graças et al., 2007; Astani et al., 2010; Yang et al., 2010; Tshilanda et al., 2020). O. americanum, recognized as American basil, is a medicinal plant which can produce essential oils and found in Bangladesh. Rosmarinic acid and oleanolic acid are the essential oils isolated from this herb. Oleanolic acid inhibits HIV-I protease whereas rosmarinic acid inhibits internal ribosome entry site of EV-71 (Aluko et al., 2012; Chung et al., 2015; Pandey et al., 2017; Tshilanda et al., 2019). O. africanum produces caffeic acid which inhibits the multiplication HSV-I. Beside, linalool has also been isolated from the essential oil of this medicinal plant havinganti-ADV-11 activity (Romeilah et al., 2010; Ikeda et al., 2011; Pandey et al., 2017). O. forsskaolii is known as wild Amazonian basil which produces ursolic acid which exhibits anti-HCV activity. Moreover, O. carnosum showed anti-HSV-I and II activities due to presence of transanethole which inhibits multiplication of HSV-I and II (Tshilanda et al., 2020).

\section{Meliaceae}

Azadirachta indica A. Juss., commonly known as "neem", is a member of Meliaceae family which is found almost everywhere in Bangladesh. This medicinal plant has a lot of medicinal properties and so, has been used for health management from ancient time in folklore, Ayurvedic, and Unani medicinal systems. At a therapeutic concentration of $50-100 \mu \mathrm{g} / \mathrm{ml}$, aqueous extract of A. indica bark remarkably blocked the entry of HSV-I into host cells. Virucidal activity against CVB-B4 was observed by the extract of A. indica leaves (Alzohairy, 2016). Gedunin and pongamol are the antiviral biocompounds extracted from $A$. indica having activity against DENV. Gedunin showed 
significant binding affinity to NS3 RNA polymerase and NS3 protease helicase (mediate the synthesis of DENV proteins and genetic materials in the host cell) as well as capsid and envelope proteins (required for entry of DENV into host cells) (Rao and Yeturu, 2020). Moreover, "neem capsule" is under clinical trial for prophylaxis and prevention of COVID-19 infection (Nesari et al., 2021). Melia azedarach L. is another antiviral medicinal plant from Meliaceae family which has been reported for inhibitory activities against vesicular stomatitis (VSV) and HSV-I. A meliacarpin named limonoid 1-cinnamoyl-3,11dihydroxymeliacarpin has been isolated from ethyl acetate extract of the leaves of this plant which showed inhibitory activities against VSV ( $\mathrm{IC}_{50}$ values of $\left.6 \mu \mathrm{M}\right)$ and HSV-1 $\left(\mathrm{IC}_{50}\right.$ values of $20 \mu \mathrm{M})$ (Alché et al., 2003).

\section{Moraceae}

Ficus religiosa L. belongs to the family Moraceae which is used in traditional Ayurvedic and Unani medicines for healing cough, wheezing and asthma as well as sexually transmitted infections like gonorrhea and genital ulcers. This medicinal plant exhibits numerous antiviral activities. A study demonstrated that ethanolic extract of the bark of F. religiosa inhibited Human rhinoviruses (HRV) $\left(\mathrm{EC}_{50}\right.$ value: $\left.5.52 \mu \mathrm{g} / \mathrm{ml}\right)$ by interfering the late steps of replicative cycle. Aqueous extract showed inhibitory activity against respiratory syncytial virus (RSV) $\left(\mathrm{EC}_{50}\right.$ value: $2.23-4.37 \mu \mathrm{g} / \mathrm{ml}$ ) by partial inactivation as well as interfering attachment to host cells (Cagno et al., 2015). Another study stated that aqueous and chloroform extracts of bark were active against HSV-II and acyclovir-resistant strain. The underlying mechanism of the aqueous extract involved direct inactivation of viral activity whereas chloroform extract suppressed the attachment and entry of virus to host cell membrane along with inhibition of viral progeny formation (Ghosh et al., 2016).

Artocarpus genus is another source of antiviral medicinal plant species. Artocarpus integer (Thunb.) Merr., Artocarpus heterophyllus Lam., Artocarpus camansi Blanco and Artocarpus altilis (Parkinson ex F.A.Zorn) Fosberg are the species of this genus which have antiviral activity. A. integer has been reported to have activity against rotavirus (simian rotavirus, SA11 and human rotavirus, HCR3 strains) (Gonçalves et al., 2005). Another study showed that dichloromethane extract of the leaves of $A$. heterophyllus showed strong anti-HCV ( $\mathrm{IC}_{50}$ value: $1.5 \pm 0.6 \mu \mathrm{g} /$ $\mathrm{ml}$ ) without major toxicity, whereas that of $A$. altilis and $A$. camansi showed moderate anti-HCV activities ( IC $_{50}$ values: $6.5 \pm$ 0.3 and $9.7 \pm 1.1 \mu \mathrm{g} / \mathrm{ml}$ respectively). The underlying mechanism of such potent anti-HCV activity of $A$. heterophyllus involved synergistic effects such as direct virucidal activity (inhibition of viral entry) and inhibition of replication of RNA and expression of viral protein at higher concentration (Hafid et al., 2017).

\section{Phyllanthaceae}

Phyllanthus niruri L., a member of Phyllanthaceae family is a medicinal plant found in Bangladesh which is used traditionally for management of edema, constipation, helminthiasis, dysentery, diarrhea, and pain. This plant possesses antiviral activity as well. Aqueous extract of whole plant has been reported to inhibit endogenous DNA polymerase of HBV and woodchuck hepatitis virus (WHV) (Tan et al., 2013). Another study stated that ethanolic extract of $P$. niruri has Anti-HCV activity ( $\mathrm{IC}_{50}$ value: $\left.4.14 \mu \mathrm{g} / \mathrm{ml}\right)$. Apart from this, it showed synergistic activity (4-fold) with an established drug, a NS3 protease inhibitor named simeprevir. Phyllanthin and hypophyllantin have been identified from this plant which showed binding to a protein, 4 GAG required for entry of $\mathrm{HCV}$ to host cells in a in silico molecular docking assay (Wahyuni et al., 2019).

\section{Piperaceae}

Piper longum L. and Piper nigrum L. are the two most common species of Piperaceae family which are cultivated in Bangladesh as spices of cooking. Both of these species exhibit a number of medicinal properties and thus, are used as folklore and traditional medicines from primordial times. Seeds of these medicinal plants have been reported for inhibitory activities on vesicular stomatitis indiana virus (VSV-IN) and human para influenza virus (PIV) (Priya and Saravana Kumari, 2017). P. longum contains piperine which is a potent anti-HBV compound functioning against the secretion of HBsAg (Selectivity Index, SI: 15.7) and HBeAg (SI: 16.8) (Jiang et al., 2013). Furthermore, $P$. nigrum contains guaiol which has been reported by an in silico study to possess inhibitory potential to 6LU7 and 7JTL (crucial targets of coronavirus) (Pandey et al.).

\section{Poaceae}

Cynodon dactylon L. is a non-toxic and edible grass belonging to Poaceae family which is known as durva grass or Bermuda grass It is found all over the countryside of Bangladesh and used as expectorant, emetic, laxative, coolant, analgesic, aphrodisiac, alexipharmic, emmenagogue, and so others. This medicinal plant is very effective against bovine coronavirus infection $(\mathrm{BCoV})$ which functions by inhibiting protease enzyme. As this viral strain has some common features with SARS-CoV and SARS-CoV-2, it can be used as dietary intervention of COVID-19 (Nalanagula, 2020).

\section{Rosaceae}

Rosa centifolia L., a flowering plant of Rosaceae family, is found in Bangladesh and known as Cabbage rose. The leave of this plant has antiviral activity. Methanolic extract of the leaves of $R$. centifolia L showed anti-HIV activity (Palshetkar et al., 2020).

\section{Rubiaceae}

Hedyotis scandens Roxb. is a medicinal plant of Rubiaceae family found in tribal hill area of Bangladesh. This plant is used as folklore medicine in Chakma tribe. Two antiviral bioactive compounds have been isolated from ethanolic extract of the whole plant namely maltol 60-b-D-apiofuranosyl-b-Dglucopyranoside, and grevilloside G. These phytocompounds showed anti-RSV activity. $\mathrm{IC}_{50}$ values for these compounds were 20 and $25 \mu \mathrm{g} / \mathrm{ml}$ respectively (Wang et al., 2013).

\section{Rutaceae}

Aegle marmelos (L.) Corrêa, a member of Rutaceae family, is a food producing plant which is found everywhere in Bangladesh. It is commonly known as bael or stone apple or wood apple. In 
Ayurveda, various parts of this plant are used because of having antidiarrhoeal, antimicrobial, antiviral, radioprotective, anticancer, chemopreventive, antipyretic, ulcer healing, antigenotoxic, diuretic, antifertility, and anti-inflammatory properties. This plant produces a bioactive compound named seselin having activity against multiple targets of SARS-CoV-2. In silico molecular docking study showed that seselin has inhibitory potential to the receptors SARS-CoV-2S protein (binding energy: $6.6 \mathrm{kcal} / \mathrm{mol}), \mathrm{COVID}-19 \mathrm{main}$ protease $(-6.9 \mathrm{kcal} / \mathrm{mol})$, and free enzyme of the SARS-CoV-2 (2019-nCoV) main protease (-6.7 kcal $/ \mathrm{mol}$ ) (Nivetha et al., 2021).

A number of citrus fruits producing medicinal plants namely Citrus limon (L.) Osbeck, Citrus sinensis (L.) Osbeck, and Citrus paradisi Macfad. are also found in this family which are commonly known as lemon, orange and grapefruit sequentially. All of them are very rich sources of vitamin $\mathrm{C}$ which fastens healing of COVID19 by boosting immunity (Bellavite and Donzelli, 2020). Essential oils extracted from the fruits of these medicinal plants have been reported for having inhibitory potential to HAV (Battistini et al., 2019). Potent antiviral compounds named hesperidin and luteolin have been isolated from fruit of $C$. sinensis. An in silico study has demonstrated that hesperidin showed efficacy to inhibit spike protein and Mpro that modulate the immature proteins (ppla and ppalb) to the complex and functional one to progress replication process of SARS-CoV-2 (Bellavite and Donzelli, 2020). Furthermore, luteolin has also been reported for having inhibitory activities against ACE2 receptor (both of the subtypes AT1 and AT2) and RdRp enzyme by an in silico assay (Goyal et al., 2020).

\section{Theaceae}

Camellia sinensis (L.) Kuntze belonging to the family Theaceae is known as tea or green tea which is considered as the most popular drink in worldwide. In Bangladesh, this plant is cultivated in two fairly divergent ecological zones such as Surma valley in greater Sylhet and Halda valley in Chittagong (Mamun, 2019). The novel antiviral bioactive compounds namely epigallocatechin-3-gallate (EGCG), epicatechin gallate (ECG) and epicatechin (EC) have been isolated from the leaves of this plant. EGCG has been reported for surprising and divergent antiviral activities. It binds to virion surface proteins and blocks the attachment of HSV-I to heparan sulfate of host cells. It inhibits RNA and DNA synthesis as well as antigen expression in HBV. It has broadspectrum antiviral activities on $\mathrm{HCV}$, IAV, murine cytomegalovirus (mCMV), vesicular stomatitis virus (VSV), and reovirus as well. Apart from these, EGCG showed potency to inhibit HIV reverse transcriptase by downregulation of the expression of the HIV p24 antigen. A destructive effect has been observed on HIV-I viral particle. It interferes with HIV-I attachment to host cell surface too. Moreover, DENV, Japanese encephalitis virus (JEV), tick-borne encephalitis virus (TBEV), Zika virus (ZIKV), CHIKV, EV-71, and rotaviruses are also inhibited by EGCG (Xu et al., 2017).

\section{Urticaceae}

Boehmeria nivea L. is the only species of Urticaceae family which exhibits antiviral activity. It is found in Bandarban, Khagrachari and Rangamati area of Bangladesh and traditionally used to prevent miscarriage as well as promote the drainage of pus and healing of wound and infections. A study demonstrated that ethanolic extract of the root exhibits anti-HBV activity. The possible mechanism suggested by the author involved potential inhibition of the expression of HBsAg and DNA of HBV (Chang et al., 2010).

\section{Zingiberaceae}

Zingiber officinale Roscoe belongs to the family Zingiberaceae which is commonly known as ginger and cultivated in Bangladesh as a prime spice of cooking. In Ayurveda, the rhizome of this herb is used from pre-historic time because of having anti-arthritis, anti-inflammatory, antidiabetic, antibacterial, antifungal, and anticancer properties. Aqueous extract prepared from the freeze dried powder of the rhizome of this herb showed anti$\mathrm{HCV}$ and anti-CHIKV activities. Active metabolites gingeronone $A$ and 6-gingerol, isolated from the rhizome of $Z$. officinale have been reported for having anti-SARS-CoV-2 activity in molecular docking studies. Besides, 6-gingerol exhibits efficacy to inhibit SARS CoV-2 by interacting viral proteases, RNA binding protein, and Spike protein (Rathinavel et al., 2020). On the other hand, gingeronone A inhibits main protease (6LU7) and SARS-CoV-2 ORF8 (7JTL) (Pandey et al., 2021).

Curcuma longa $\mathrm{L}$. is another species of Zingiberaceae family having numerous medicinal properties. It is also a spice used as foodstuff and cultivated in Bangladesh. It is used as herbal medicine for managing rheumatoid arthritis, chronic anterior uveitis, conjunctivitis, skin cancer, small pox, chicken pox, wound healing, urinary tract infection, and cancers. Aqueous extract of the rhizome of this herb has anti-HBV activity. It blocked $\mathrm{HBx}$ gene transcription by suppressing $\mathrm{HBV}$ enhancer $\mathrm{I}$ and $\mathrm{X}$ promoter through p53 protein (Kim et al., 2009). This herb produces curcumin which possesses diverse pharmacological activities. It inhibits HIV, DENV, CHIKV, ZIKV, VSV, IAV, RSV, EV71 and Kaposi's sarcoma-associated herpesvirus by multiple pathways (Jennings and Parks, 2020) described in Table 3. Furthermore, a randomized controlled trial has proved the effectiveness of curcumin for pre-exposure prophylaxis of COVID-19 (Table 2). This prophylactic activity may be due to (a) multiple antiviral mechanisms of action (interact directly with viral membrane proteins, disrupt viral envelope, inhibit viral protease, and induce host antiviral response by boosting immunity) against numerous types of enveloped viruses (as SARS-CoV-2 is a enveloped virus) (b) protection from severe pneumonia (by targeting NF- $\kappa \mathrm{B}$, IL-6 trans signal, and HMGB1 pathways), and (c) safe and welltolerated in both healthy and diseased human subjects (Thimmulappa et al., 2021).

\section{MECHANISTIC INSIGHT OF ANTIVIRAL ACTIVITIES OF THE PLANT METABOLITES DERIVED FROM MEDICINAL PLANTS}

From the ancient times, medicinal plants are considered as one of the major priorities of treating illness. Search of antiviral drugs 
TABLE 3 | Bioactive compounds with antiviral mechanism isolated from medicinal plants.

Andrographolide

Anisotine

Oleanolic acid

Mangiferin

(+)-pinoresinol 4-O-(6"-Ovanilloyl)- $\beta$-d-glucopyranoside

Quercetin, catechin hydrate, and Aloe vera (L.) Burm.f. kaempferol

Feralolide

Coumestan kaempferol-3-O-(6"-O-E-

p-coumaroyl)-

$\beta$-D-glucopyranoside

Anolignan A Anolignan B

Humulene epoxide

(+)-catechin

Flacourtosides A and E Betulinic acid $3 \beta$-caffeate

(+)-cycloolivil-4'-O- $\beta$-d-

glucopyranoside

Ursolic acid

Apigenin

Rosmarinic acid

$\beta$-caryophyllene

Trans-anethole

Ajoene

Allicin

Allium sativum $\mathrm{L}$.

Alliin, diallyl sulfide, and garlicin

Allium sativum L.

Allitridin

Plants

Mechanism of antiviral

activity

Andrographis paniculata (Burm.f.) Nees

Justicia adhatoda L.

Achyranthes aspera L. Ocimum americanum L.

Mangifera indica L.

Calotropis gigantea (L.) Dryand.

Aloe vera (L.) Burm.f.

Eclipta prostrata $L$.

Bombax ceiba $L$.

Anogeissus acuminata (Roxb. ex DC.) Wall. ex Guillem. \& Perr

Cyperus rotundus $L$.

Albizia procera (Roxb.) Benth.

Flacourtia indica (Burm.f.) Merr.

Swertia angustifolia var. pulchella (D. Don) Burkill

Ocimum tenuiflorum L. Ocimum

basilicum L. Ocimum

gratissimum L.

Ocimum basilicum L.

Ocimum tenuiflorum L. Ocimum americanum L.

Ocimum campechianum Mill.

Ocimum carnosum (Spreng.) Link \& Otto ex Benth.

Allium sativum $\mathrm{L}$. a) Inhibit the expression of HSV-I enveloped glycoproteins D and C

b) Inhibit HIV-induced cell cycle dysregulation and

increase CD4 ${ }^{+}$lymphocyte

c) Inhibit the expression of EBV lytic proteins, Rta, Zta and EA-D

Inhibit Mpro of SARS-CoV-2 which mediates the cleavage of polyprotein to get matured and acquire infectivity

a) Inhibited the early stage of multiplication (2-6 h of post infection) of HIV

b) Inhibit protease enzyme of HIV-I

Inhibit HSV-1 virus duplication

Inhibit NF-kB pathway and viral ribonucleoproteins

nuclear export of $\mathrm{H} 1 \mathrm{~N} 1$ virus

a) Inhibit influenza-A virus ( $\mathrm{H} 1 \mathrm{~N} 1$ or $\mathrm{H} 3 \mathrm{~N} 2$ ), induce autophagy and inhibit M2 viral mRNA synthesis, and $\mathrm{M} 2$ protein expression

b) Inhibit Mpro of SARS CoV-2

c) Quercetin inhibited ACE2 receptor of SARS CoV-2 Inhibit the main protease (3CLpro) responsible for the replication of SARS-CoV-2

Inhibit HCV NS5B protein leading to RNA replication

a) Inhibit cytopathic effect of RSV

b) Inhibit ORF 3a protein of SARS-CoV-2 leading to interference of virus release mechanism and reduce apoptosis

Inhibit HIV-I reverse transcriptase (RT)

Inhibit four target proteins of SARS-CoV-2 such as spike glycoprotein, papain-like protease (PLpro), 3chymotrypsin-like protease (3CLpro) and RNAdependent RNA polymerase (RdRp)

a) Inhibit integrase enzyme of human influenza virus-I by interacting with Thr66, Gly148, and Glu152.

b) Inhibit Mpro enzyme of SARS CoV-2

Inhibit DENV RNA polymerase

Inhibit HBsAg and HBeAg secretion and HBV DNA replication

a) Inhibit replication of HSV-I and II

b) Inhibit multiplication of $\mathrm{HCV}$

a) Inhibit ACE2 receptor and 3CLpro of SARS-CoV-2 b) Inhibit replication of HBV

a) Inhibit replication of HSV-I and II

b) Inhibit protease enzyme of HSV-I and II

Inhibit replication of HSV-I and II

Inhibit multiplication of HSV-I and II

a) Prevent HIV-induced destruction of CD + cells

b) Enhance cellular immunity

c) Inhibit virus-cell attachment and viral reverse

transcriptase of HIV-I

d) Induce apoptosis of HCMV infected cells

a) Inhibit the entry of HSV-I and II, PIV-3, W, VSV and $\mathrm{HRV}-2$ by disrupting viral envelope and cell membrane b) Inhibit the replication of REV by downregulation of ERK/MAPK pathway

Inhibit DENV by diminishing inflammation by

suppressing oxidative stress

a) Inhibit viral DNA synthesis through inhibition of immediate-early antigen expression of HCMV
References

Calabrese et al. (2000); Wiart et al. (2005); Lin et al. (2008)

Ghosh et al. (2021)

Mukherjee et al. (2013); Tshilanda et al. (2019)

Al-Rawi et al. (2019)

Parhira et al. (2014)

Choi et al. (2019); Goyal et al. (2020); Khaerunnisa et al. (2020); Solnier and Fladerer (2020)

Mpiana et al. (2020)

Kaushik-Basu et al. (2008)

Schwarz et al. (2014); Zhang et al.

(2015); Ren et al. (2020)

\section{El-Ansari et al. (2020)}

Amparo et al. (2021)

Panthong et al. (2015); Khaerunnisa et al. (2020)

\section{Bourjot et al. (2012)}

Zhou et al. (2015)

Tshilanda et al. (2020)

Benencia and Courreges (2000); Goyal et al. (2020)

Tshilanda et al. (2020)

Tshilanda et al. (2020)

Astani et al. (2010)

Rouf et al. (2020)

Rouf et al. (2020)

Rouf et al. (2020)

Rouf et al. (2020)

(Continued on following page) 
TABLE 3 | (Continued) Bioactive compounds with antiviral mechanism isolated from medicinal plants.

\begin{tabular}{|c|c|c|c|}
\hline Bioactive compounds & Plants & $\begin{array}{l}\text { Mechanism of antiviral } \\
\text { activity }\end{array}$ & References \\
\hline & & $\begin{array}{l}\text { b) Inhibit viral replication by suppressing viral IEG gene } \\
\text { transcription } \\
\text { c) Enhance Treg expansion and Treg-mediated anti- } \\
\text { HCMV immunosuppression }\end{array}$ & \\
\hline Gedunin & Azadirachta indica A. Juss. & $\begin{array}{l}\text { Inhibit NS3 RNA polymerase and NS3 protease } \\
\text { helicase (mediate the synthesis of DENV proteins and } \\
\text { genetic materials in the host cell) as well as capsid and } \\
\text { envelope proteins (required for entry of DENV into host } \\
\text { cells) }\end{array}$ & Rao and Yeturu, (2020) \\
\hline Phyllanthin and hypophyllantin & Phyllanthus niruri L. & $\begin{array}{l}\text { Bind to } 4 \text { GAG protein of HCV leading to interference in } \\
\text { viral entry to host cells }\end{array}$ & Wahyuni et al. (2019) \\
\hline Piperine & Piper longum L. & Inhibit the secretion of $\mathrm{HBsAg}$ and $\mathrm{HBeAg}$ of $\mathrm{HBV}$ & Jiang et al. (2013) \\
\hline Guaiol & Piper nigrum L. & Inhibit 6LU7 and 7JTL of SARS-CoV-2 & Pandey et al. (2021) \\
\hline Seselin & Aegle marmelos (L.) Corrêa & $\begin{array}{l}\text { Inhibit the receptors SARS-CoV-2S protein, COVID- } \\
19 \text { main protease, and free enzyme of the SARS-CoV- } \\
2 \text { (2019-nCoV) main protease }\end{array}$ & Nivetha et al. (2021) \\
\hline Hesperidin & Citrus sinensis (L.) Osbeck & $\begin{array}{l}\text { Inhibit ACE2 receptor, RdRp, spike protein and Mpro } \\
\text { of SARS-CoV-2 (under clinical trials, phase-II) }\end{array}$ & $\begin{array}{l}\text { Bellavite and Donzelli (2020); Goyal et al. } \\
\text { (2020) }\end{array}$ \\
\hline $\begin{array}{l}\text { Epigallocatechin-3-gallate } \\
\text { (EGCG) }\end{array}$ & Camellia sinensis (L.) Kuntze & $\begin{array}{l}\text { a) Inhibit Mpro enzyme, and S protein-receptor } \\
\text { interaction of SARS CoV-2 } \\
\text { b) Inhibit HIV reverse transcriptase by downregulation } \\
\text { of the expression of the HIV p24 antigen } \\
\text { c) inhibit RNA and DNA synthesis and antigen } \\
\text { expression in HBV } \\
\text { d) Block the attachment of HIV-I and HSV-I to of host } \\
\text { cells }\end{array}$ & $\begin{array}{l}\text { Xu et al. (2017); Goyal et al. (2020); } \\
\text { Khaerunnisa et al. (2020); Henss et al. } \\
\text { (2021) }\end{array}$ \\
\hline Epicatechin gallate (ECG) & Camellia sinensis (L.) Kuntze & Inhibit Mpro enzyme of SARS CoV-2 & $\begin{array}{l}\text { Goyal et al. (2020); Khaerunnisa et al. } \\
\text { (2020) }\end{array}$ \\
\hline 6-Gingerol & Zingiber officinale Roscoe & $\begin{array}{l}\text { Inhibit SARS CoV-2 by interacting viral proteases, } \\
\text { RNA binding protein and Spike protein }\end{array}$ & Rathinavel et al. (2020) \\
\hline Gingeronone A & Zingiber officinale Roscoe & Inhibit 6LU7 and 7JTL of SARS-CoV-2 & Pandey et al. (2021) \\
\hline Curcumin & Curcuma Longa L. & $\begin{array}{l}\text { a) SARS-CoV-2: Inhibit ACE2 receptor, viral replication } \\
\text { and Mpro } \\
\text { b) HIV: Inhibit replication and degrade viral protein } \\
\text { c) DENV: Inhibit viral entry, replication and protease } \\
\text { enzyme } \\
\text { d) IAV: Inhibit replication } \\
\text { e) EV } 71 \text { : Downregulation of protein expression } \\
\text { f) ZIKV, CHIKV, VSV, and RSV: Inhibit viral attachment } \\
\text { to host cell surface }\end{array}$ & $\begin{array}{l}\text { Jennings and Parks (2020); Khaerunnisa } \\
\text { et al. (2020); Manoharan et al. (2020) }\end{array}$ \\
\hline
\end{tabular}

TABLE 4 | Available commercial herbal preparations from antiviral medicinal plants in Bangladesh

\begin{tabular}{|c|c|c|c|}
\hline Product & Species & Used part & Name of the Company \\
\hline Kalomegh & Andrographis paniculata (Burm.f.) Nees & Leaf & $\begin{array}{l}\text { Square Herbal and Nutraceuticals Ltd. } \\
\text { ACME Laboratories Ltd. }\end{array}$ \\
\hline Tulsi & Ocimum tenuiflorum Burm. f. & Leaf & $\begin{array}{l}\text { Square Herbal and Nutraceuticals Ltd. } \\
\text { ACME Laboratories Ltd. }\end{array}$ \\
\hline Bashak & Justicia adhatoda L. & Leaf & $\begin{array}{l}\text { Square Laboratories Ltd. } \\
\text { ACME Laboratories Ltd. }\end{array}$ \\
\hline Garlic oil & Allium sativum $\mathrm{L}$. & Bulb & Square Herbal and Nutraceuticals Ltd. \\
\hline Chirata & Swertia angustifolia var. pulchella (D. Don) Burkill & Whole plant & Drug International Ltd. \\
\hline Aloe vera gel & Aloe vera (L.) Burm.f. & Leaf & Drug International Ltd. \\
\hline
\end{tabular}

from plant sources is crucial due to fatality and repeated mutations of viruses. Apart from these, new and deadly viral strains are infecting humans time to time. In the last few decades, advancement of synthetic medicinal chemistry has shed light on discovery of synthetic antiviral drugs. A number of synthetic antiviral drugs have been developed which are effective against numerous viruses. Unfortunately, these drugs produce serious adverse effects for continuous administrations. Moreover, many 


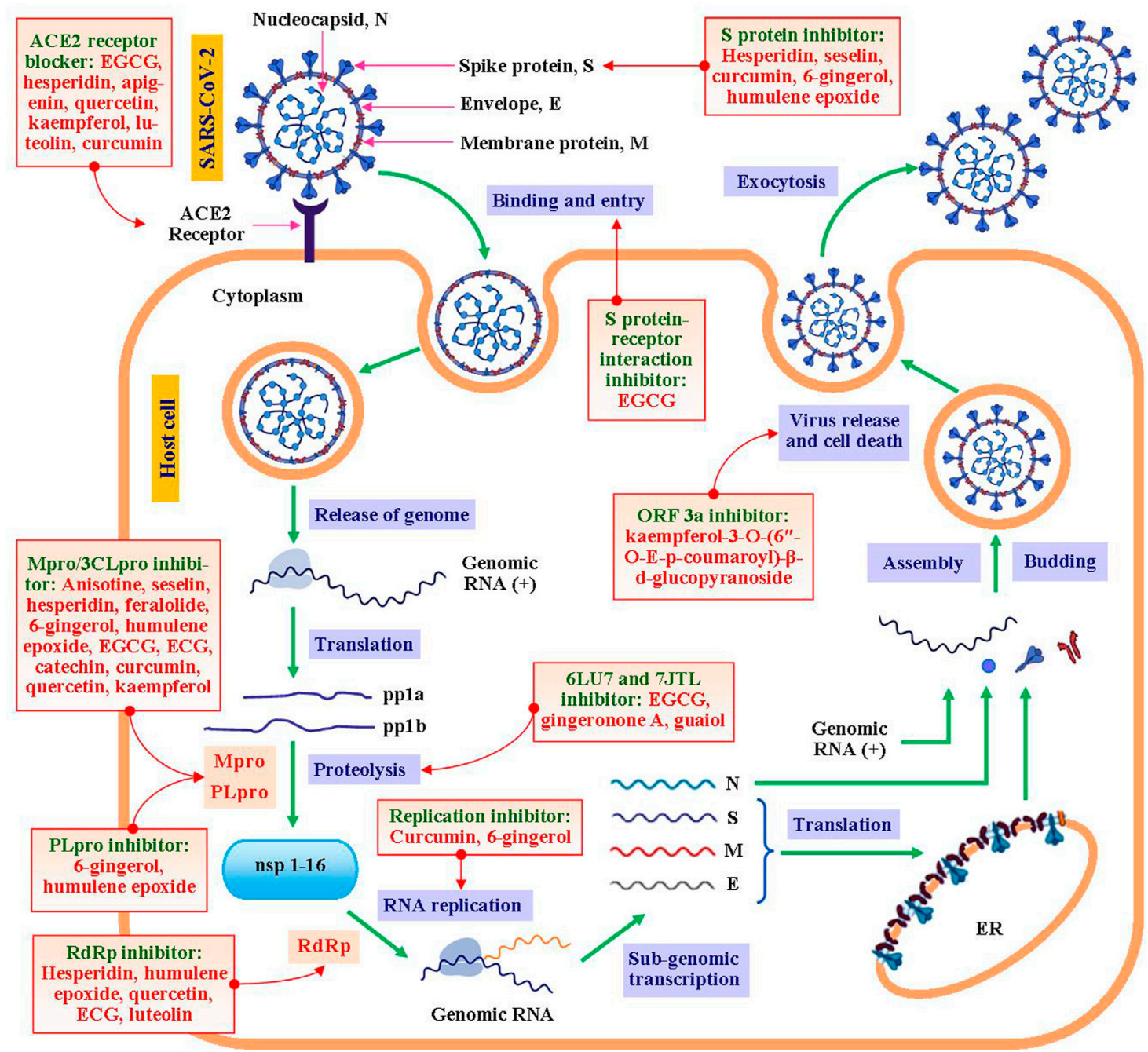

FIGURE 1 | Impact of bioactive metabolites derived from Bangladeshi medicinal plants on molecular targets of various steps of multiplication process of SARSCoV-2. ACE2, angiotensin converting enzyme 2; N, Nucleocapsid; S, M, E:,spike, membrane, envelope proteins; pp1a, pp1b, nonfunctional polypeptides; nsp, nonstructural proteins; Mpro, main protease; 3CLpro, 3-chymotrypsin like protease; PLpro, papain like protease; RdRp, RNA dependent RNA polymerase; RNA (+), positive-sense RNA; and ER, endoplasmic reticulum.

of the synthetic antiviral drugs are ineffective against mutant or resistant strains of viruses. Therefore, the demand for non-toxic antiviral drugs having efficiency to cure viral infections completely still persists. Due to scientific evidences on antiviral potential of naturally produced compounds and their mild side-effects, researchers place their attention extensively on natural resources, especially on plants to search for bioactive metabolites with potent antiviral activities and adequate drug-properties. Pharmaceuticals and nutraceuticals are also paying attention to herbal preparations by using crude extract, syrup, essential oil, and gel extracted from medicinal plants. Interestingly, in recent years, these industries have manufactured them as commercial drug products to treat specific diseases (Table 4).

At present, the outbreak of COVID-19 has turned into an evolving worldwide health crisis. Few years back, ZIKV, EV,
DENV, and CHIKV have affected a lot of people. Along with these, HIV infection and its treatment still remain unresolved. About 46 medicinal plants available in Bangladesh have been enlisted to have broad-spectrum antiviral activities against a number of viruses. Though phytochemical profiles of these plants are not yet revealed completely, 36 of bioactive metabolites have been reported to exhibit potential antiviral activities with revealing the underlying mechanisms of their activities. Table 3 showed their sources and potential mechanism of activities.

\section{Effects on SARS-CoV-2}

COVID-19, considered as the deadliest viral infection in present time worldwide. SARS-CoV-2 is the responsible strain belonging to $\beta$-coronavirus genus which is spherical shaped enveloped virus packed with single stranded positive-sense $(+)$ genomic RNA. It 
contains ultra-structural spike proteins on the surface having crown resembled shape (corona) appearance. The genome of this virus encodes structural, accessory, and non-structural proteins. Nucleocapsid (N), spike protein (S), membrane protein (M), and envelope protein $(\mathrm{E})$ are the major structural proteins (Haake et al., 2020). The multiplication of this virus involves several steps mediated by numerous functional molecules which might be important targets for development of the drug therapy for this virus (V'kovski et al., 2021). These cellular and molecular targets of coronavirus can be inhibited and/or interfered by bioactive metabolites derived from medicinal plants found in Bangladesh (Figure 1).

This multiplication process is initiated by viral attachment to host cell surface followed by endocytosis via binding and interaction of viral $S$ protein to angiotensin converting enzyme-2 receptor (ACE2 receptor) on the host cell surface. Inhibitor of S protein, blocker of ACE2 receptor or interferer of $S$ protein-ACE2 receptor interaction might inhibit viral entry to host cell. A number of in silico studies demonstrated that numerous metabolites derived from Bangladeshi medicinal plants including (a) hesperidin, seselin, 6-gingerol, and humulene epoxide interacted with and inhibited $S$ protein of SARS-CoV-2 (Bellavite and Donzelli, 2020; Rathinavel et al., 2020; Amparo et al., 2021; Nivetha et al., 2021); (b) hesperidin, kaemferol, apigenin, luteolin, quercetin, and curcumin inhibited ACE2 receptor (Goyal et al., 2020; Manoharan et al., 2020); and (c) hesperidin, seselin, EGCG, curcumin, 6-gingerol, and humulene epoxide interfered with the interaction of S protein-receptor (Henss et al., 2021). These metabolites might be considered for development of potential SARS-CoV-2 entry inhibitors. After endocytosis, the genomic RNA gets translated to nonfunctional polypeptides which are cleaved to functional proteins via proteolytic activity of Mpro/3CLpro and PLpro enzymes. Anisotine, hesperidin, seselin, feralolide, 6-gingerol, humulene epoxide, catechin, ECG, EGCG, curcumin, quercetin, and kaempferol have been reported for exhibiting inhibition potential for main protease, Mpro/3CLpro enzyme (Bellavite and Donzelli, 2020; Khaerunnisa et al., 2020; Mpiana et al., 2020; Rathinavel et al., 2020; Amparo et al., 2021; Ghosh et al., 2021; Nivetha et al., 2021); whereas 6-gingerol and humulene epoxide inhibited PLpro enzyme (Rathinavel et al., 2020; Amparo et al., 2021) resulting inhibition of proteolysis and ending with non-infective nonfunctional proteins. Apart from these, gingeronone A and guaiol inhibited 6LU7 and 7JTL which are crucial for proteolysis mechanism (Pandey et al., 2021). The next step involves replication of genomic RNA from 16 types of nonstructural proteins (nsp 1-16) regulated by RNA dependent RNA polymerase (RdRp) which was inhibited by hesperidin, luteolin, quercetin, ECG, and humulene epoxide (Goyal et al., 2020; Amparo et al., 2021). According to latest researches regarding drug development against SARS-CoV-2 virus, ACE2 receptor blockers as well as RdRp enzyme inhibitors are considered as the most important candidates. Currently, hesperidin is under phase-II clinical trials for treatment of COVID-19 due to its potential activities against these two major targets.
Besides, curcumin and 6-gingerol have been reported for inhibiting this replication process (Khaerunnisa et al., 2020; Rathinavel et al., 2020). After translation and posttranslational maturation, the genomic RNA and proteins get assembled, and initiated exocytosis mechanism resulting apoptosis of host cell. Kaempferol-3-O-(6" -O-E-p-coumaroyl)$\beta$-d-glucopyranoside, a plant-derived bioactive compound inhibited ORF 3a, a viral protein of coronavirus involves in release mechanism (SARS-CoV-1) as well as induction of apoptosis (SARS-CoV-2) (Schwarz et al., 2014; Ren et al., 2020).

\section{Effects on HIV}

HIV, considered as one of the most fatal virus which causes acquired immunodeficiency syndrome (AIDS). This virus attacks $\mathrm{CD} 4^{+}$lymphocytes which lead to cell death and resultant immune deficiency. Thus, invention of antiretroviral therapy to combat this virus remains one of the global challenges to researchers. Multiplication of this virus involves several basic steps, such as attachment to host cell surface, entry and uncoating of genetic materials to the host cell, reverse transcription of genomic RNA with the help of reverse transcriptase (RT) enzyme followed by translocation of the DNA to host nucleus. Then, the viral DNA gets integrated into host genome and undergoes transcription resulting formation of mRNA and genetic RNA. The mRNA undergoes translation to form viral proteins which are assembled accompanied by genetic RNA in form of virion. These newly formed virions are released from host cells by rapturing plasma membranes and got matured by the help of protease enzyme (Kirchhoff, 2013).

Numerous bioactive metabolites have been tested and reported for having efficacy to block the steps of multiplications of this virus (Figure 2). Researchers demonstrated that interaction of gp120 of HIV and CD4 receptor of host cell surface has been inhibited by EGCG and ajoene (Williamson et al., 2006; Rouf et al., 2020). Reverse transcription is one of the major molecular targets of discovery of antiviral drugs against HIV. Bangladeshi medicinal plant-derived biomolecules anolignan-A, anolignan-B, ajoene, and EGCG inhibited this step by inhibiting RT enzyme. EGCG inhibits this step by interfering Nrf2, AKT, and AMPK signaling transduction pathways which are essential for regulation of viral replication. (Li et al., 2011; Zhang et al., 2012; El-Ansari et al., 2020; Rouf et al., 2020). Besides, this biomolecule affects uncoating and nuclear translocation of genetic materials indirectly by downregulation of the expression of p24 gene (Xu et al., 2017). Synthesized viral proteins are essential components for formation of new virions. Curcumin, found in Curcuma longa, has been reported for degradation of newly synthesized viral proteins (Jennings and Parks, 2020). Maturation of newly released virions is mandatory for attaining infectivity which involves protease enzyme-regulated proteolytic cleavage. This protease enzyme is inhibited by oleanolic acid (Tshilanda et al., 2019). Apart from these, immune deficiency is observed in HIV-infected patients because of decreasing the number of $\mathrm{CD}^{+}$ lymphocytes which is actually the results of plasma 


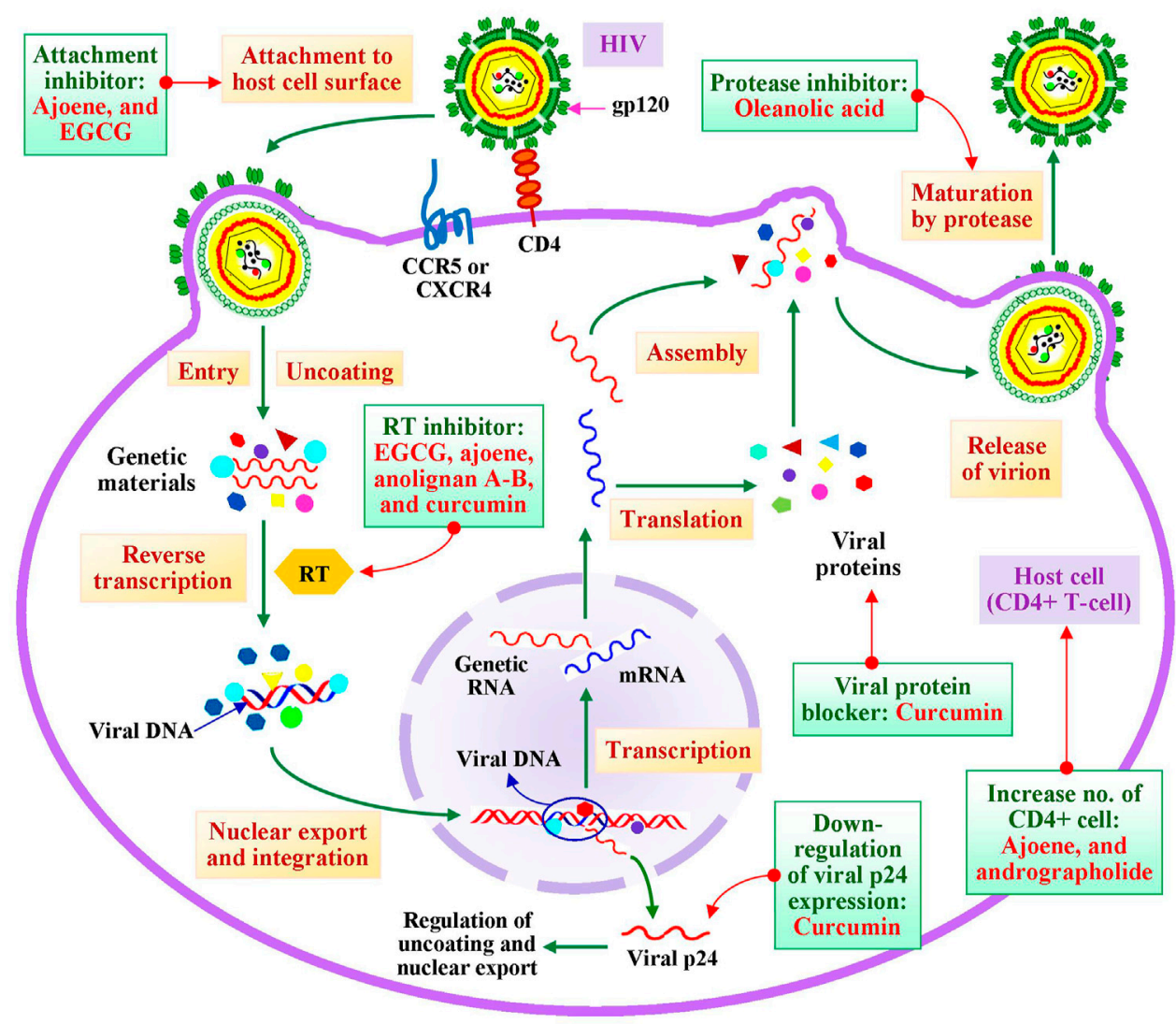

FIGURE 2 | Impact of bioactive metabolites derived from Bangladeshi medicinal plants on molecular targets of various steps of multiplication process of HIV. RT, reverse transcriptase; EGCG, epigallocatechin-3-gallate; and gp120, glycoprotein-120.

membrane disruption and subsequent cell death. Scientific research showed that ajoene blocked HIV-induced $\mathrm{CD}^{+}$cell destruction (Rouf et al., 2020). Another study stated that adrographolide treatment increased the $\mathrm{CD}^{+}$cell counts in HIV-positive patients investigating under phase-I clinical trial (Calabrese et al., 2000).

\section{Effects on HBV}

$\mathrm{HBV}$ is a unique type of virus that attacks the hepatocytes resulting severe liver infection. Its genomic material is partially double-stranded DNA, commonly known as relaxed-circular DNA or rcDNA. The multiplication process of this virus is distinctive which involves complex and sequential stages (Grimm et al., 2011). It initiates with viral attachment to $\mathrm{Na}$-taurocholate co-transporting polypeptide (NTCP), also known as sodium/bile acid cotransporter present on plasma membrane leading to genomic entry to hepatocytes. The genomic rcDNA gets translocated to nucleus where host proteins and enzymes repair it by covalent ligation of DNA double strands and form complementary closed circular DNA or ccDNA. It is a highly stable molecular template that exhibits capability to modulate the progression status of severe and barely curable chronic liver infection. After that, the transcription of
ccDNA generates subgenomic RNA (sgRNA) and pregenomic RNA (pgRNA). Bioactive molecules, such as EGCG and curcumin have been reported to inhibit this transcription step leading to reduction of viral load ( $\mathrm{Xu}$ et al., 2017; Jennings and Parks, 2020) (Figure 3).

This multiplication cycle proceeds by translation and processing of viral antigen particles from sgRNA. Hepatitis-B surface antigen (HbsAg) and hepatitis-B e antigen (HbeAg) are predominantly used screening parameter to assay anti-HBV activity. $\mathrm{HbsAg}$ is essential for viral assembly whereas $\mathrm{HbeAg}$ is a circulating protein in blood of infected patients during active replication stage. This HbeAg level is an indicator of predicting that the patient is whether infectious to others or not (Grimm et al., 2011). Piperine, ursolic acid, oleanolic acid, and (+)-cycloolivil-4'-O- $\beta$-d-glucopyranoside have been testified to decrease the synthesis of $\mathrm{HbsAg}$ and $\mathrm{HbeAg}$ in many studies (Zhou et al., 2015; Tshilanda et al., 2019; Liu et al., 2020). Quercetin has also been reported to decrease their synthesis by $60 \%$ (Parvez et al., 2020). Besides, EGCG diminished the expression of these antigens significantly (Xu et al., 2017). Alternatively, the pgRNA undergoes encapsidation followed by a complex process of reverse transcription to form single strand (-) DNA or ssDNA. This step was inhibited by EGCG and kaempferol in various investigations (Xu et al., 2017; Choi et al., 2019). This ssDNA goes through replication process to generate rcDNA which 


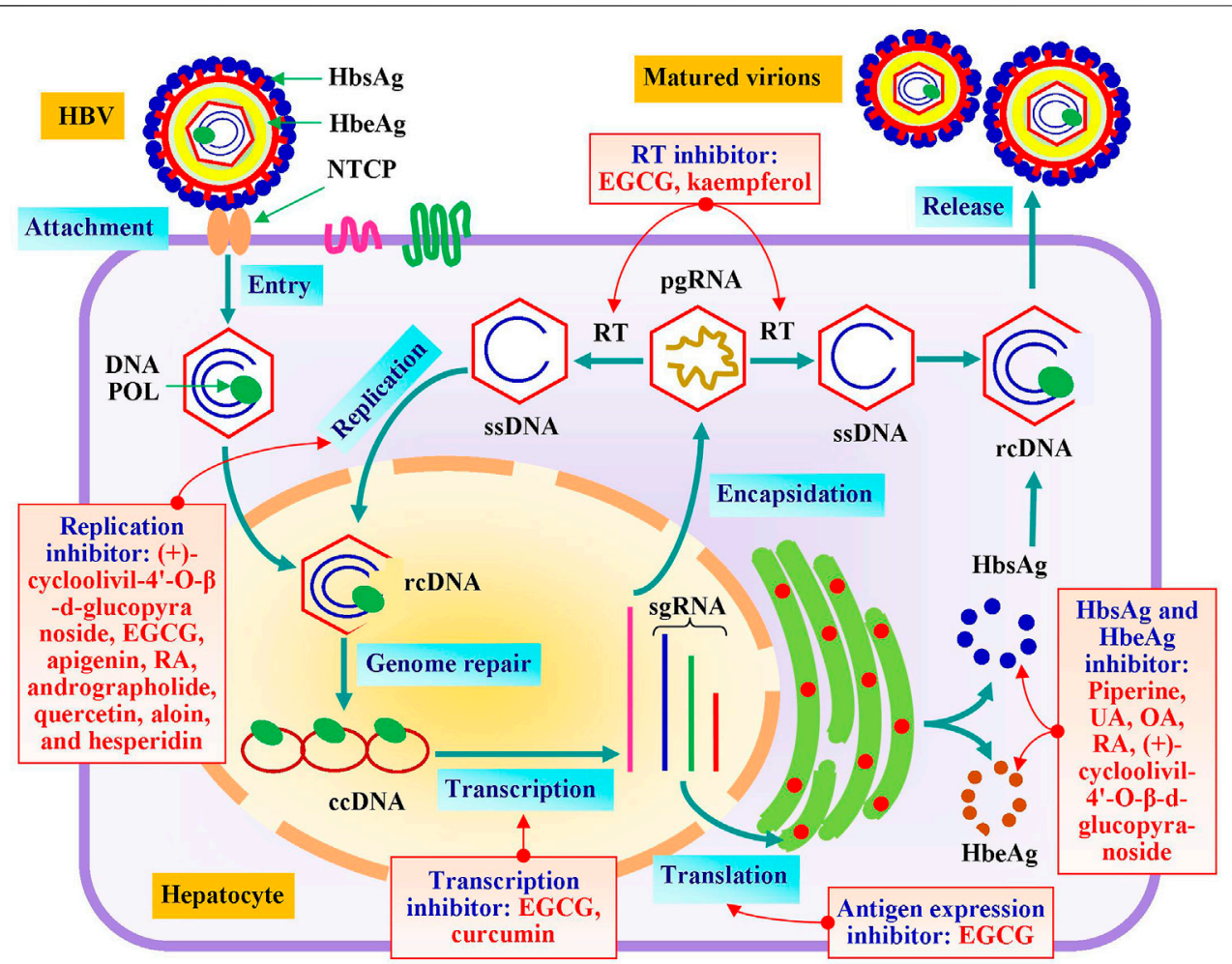

FIGURE 3 | Impact of bioactive metabolites derived from Bangladeshi medicinal plants on molecular targets of HBV. NTCP, $\mathrm{Na}^{+}$-taurocholate co-transporting polypeptide; DNA POL, DNA polymerase; RT, reverse transcriptase; rcDNA, relaxed circular DNA; ccDNA, closed circular DNA; pgRNA, pre-genomic RNA; HbsAg, hepatitis-B surface antigen; HbeAg, hepatitis-B e antigen; RA, rosmarinic acid; UA, ursolic acid; and OA, oleanolic acid.

TABLE 5 | Effective delivery systems for oral delivery of plant metabolites with antiviral activity (Ben-Shabat et al., 2020).

Plant metabolite

Andrographolide

Oleanolic acid

Quercetin

Apigenin

Curcumin

\section{Novel delivery system}

Self-microemulsion, microsphere, nanosuspension, self-nanodispersion, nanoparticle, and inclusion complex Self-microemulsion, nanoparticle, self-nanoemulsion and nanosuspension

Nanocrystal, nanoparticle, phytosome, nanoliposome, self-nanoemulsion, mixed micelle, nanoemulsion, and nanosuspension

W/O/W emulsion, O/W microemulsion, solid dispersion, mixed micelle, micropellet, phytosome, and self-microemulsion Mixed micelle, nanoparticle, solid dispersion, self-nanoemulsion, self-microemulsion, lipid carrier, co-polymeric micelle, and exosome

W/O/W, water-in-oil-in-water, O/W, oil-in-water.

gets recycled and/or gets assembled along with viral proteins to form new virions. A number of plant-derived metabolites namely (+)-cycloolivil-4'-O- $\beta$-d-glucopyranoside, EGCG, aloin, quercetin, apigenin, rosmarinic acid, andrographolide, and hesperidin have been substantiated to interfere the replication process ( $\mathrm{Lin}$ et al., 2008; Cheng et al., 2015; Zhou et al., 2015; Xu et al., 2017; Wang et al., 2018; Parvez et al., 2019a; Parvez et al., 2019b).

\section{CHALLENGES AND LIMITATIONS}

Plant metabolites possess multiple therapeutic activities. They can produce synergistic effects resulting superior therapeutic outcomes. Along with numerous advantages, a number of challenges must be overcome during drug discovery process. The major hindrance is drugability of the plant metabolites. Pharmacokinetic ADME (absorption, distribution, metabolism and elimination) parameters are the crucial factors that affect the drugability of a plant-derived compound. Fortunately, advancement of novel drug delivery systems and nanotechnologies enlighten the hope of developing plant metabolites as potential drugs. Already a number of plant metabolites have been formulated as novel drug delivery systems (Table 5). Other impending challenges are (a) procurement and authentication of plant materials; (b) application of high-throughput screening bioassays and scale-up of bioactive lead compounds; and (c) complexity 
in isolation and purification processes (Jachak and Saklani, 2007). Moreover, the toxicities of plant metabolites are sometimes overlooked during laboratory based assays which are observed during clinical trials. Isolation, purification, and bioassay of pure plant-derived compounds are relatively complex, time consuming and required so much efforts, thus failure of drug development at clinical trial phases are very disappointing (Phu et al., 2020).

\section{CONCLUDING REMARKS}

In this review, we have summarized the overview of 46 antiviral medicinal plants from 25 families cultivated and originated in Bangladesh. In most of the cases, medicinal plants are screened by preliminary in vitro and/or in silico assays for antiviral activities, but very few of them are moved forward for further studies and clinical trials. Moreover, bioactive phytochemicals are not profiled for all of these plants. From the available data regarding these plants, a total of 79 compounds with antiviral activities have been found. Amongst them, about 37 bioactive compounds have significant antiviral activities accompanied by mechanistic explanation. These compounds showed potential inhibitory

\section{REFERENCES}

Abd El-Wahab, A., El-Adawi, H., and El-Demellawy, M. (2009). In Vitro study of the Antiviral Activity of Zingiber Officinale. Planta Med. 75, PF7. doi:10.1055/s-00291234649

Al Rawi, A. A. S., Al Dulaimi, H. S. H., and Al Rawi, M. A. A. (2019). Antiviral Activity of Mangifera Extract on Influenza Virus Cultivated in Different Cell Cultures. J. Pure Appl. Microbiol. 13, 455-458. doi:10.22207/jpam.13.1.50

Alché, L. E., Ferek, G. A., Meo, M., Coto, C. E., and Maier, M. S. (2003). An Antiviral Meliacarpin from Leaves of Melia Azedarach L. Z. Naturforsch C J. Biosci. 58, 215-219. doi:10.1515/znc-2003-3-413

Alejandria, M. M. (2015). Dengue Haemorrhagic Fever or Dengue Shock Syndrome in Children. BMJ Clin. Evid. 2015, 0917. doi:10.1016/ j.ajme.2014.06.002

Aluko, B., Oloyede, O., and Afolayan, A. (2012). Phytochemical and Nutrient Compositions of the Leaves of Ocimum Canum Sims. Afr. J. Biotechnol. 11, 12697-12701. doi:10.5897/ajb11.3418

Alzohairy, M. A. (2016). Therapeutics Role of Azadirachta indica (Neem) and Their Active Constituents in Diseases Prevention and Treatment. Evidence-Based Complement. Altern. Med. 2016, 7382506. doi:10.1155/ 2016/7382506

Amparo, T. R., Seibert, J. B., Silveira, B. M., Costa, F. S. F., Almeida, T. C., Braga, S. F. P., et al. (2021). Brazilian Essential Oils as Source for the Discovery of New Anti-COVID-19 Drug: a Review Guided by In Silico Study. Phytochem. Rev., 1-20. doi:10.1007/s11101-021-09754-4

Arbab, A. H., Parvez, M. K., Al-Dosari, M. S., and Al-Rehaily, A. J. (2017). In Vitro evaluation of Novel Antiviral Activities of 60 Medicinal Plants Extracts against Hepatitis B Virus. Exp. Ther. Med. 14, 626-634. doi:10.3892/etm.2017.4530

Astani, A., Reichling, J., and Schnitzler, P. (2010). Comparative Study on the Antiviral Activity of Selected Monoterpenes Derived from Essential Oils. Phytother Res. 24, 673-679. doi:10.1002/ptr.2955 activities against SARS-CoV-2, HIV, HBV, HCV, HSV, DENV, influenza virus and so others. EGCG, oleanolic acid, hesperidin, quercetin, curcumin, kaempferol, and andrographolide showed activity against multiple viruses. Adequate studies are not available regarding structure activity relationship of these bioactive compounds which are crucial to develop drugs active against fatal viruses. Thus, for the development of desired antiviral drug molecules from these medicinal plants, further investigations should be necessary to unveil the mechanism of antiviral activities of the isolated bioactive metabolites along with enlightenment of the structure activity relationship.

\section{AUTHOR CONTRIBUTIONS}

SB: Generated the idea and contributed to writing the manuscript followed by editing; KM, AA, and RB: Contributed to writing the most important sections of the manuscript including the drawing of the figures; MA: Contributed to the dissemination of ideas on viral diseases and selection of Bangladeshi herbal plants to be used with evidence for writing the manuscript. He also played a vital role in editing the manuscript. All authors contributed to the article and approved the submitted version.

Astani, A., Reichling, J., and Schnitzler, P. (2011). Screening for Antiviral Activities of Isolated Compounds from Essential Oils. Evidence-Based Complement. Altern. Med. 2011, 253643. doi:10.1093/ecam/nep187

Battistini, R., Rossini, I., Ercolini, C., Goria, M., Callipo, M. R., Maurella, C., et al. (2019). Antiviral Activity of Essential Oils against Hepatitis A Virus in Soft Fruits. Food Environ. Virol. 11, 90-95. doi:10.1007/s12560-019-09367-3

Behbahani, M., Mohabatkar, H., and Soltani, M. (2013). Anti-HIV-1 Activities of Aerial Parts of Ocimum Basilicum and its Parasite Cuscuta Campestris. J. Antivir. Antiretrovir. 5, 57-61. doi:10.4172/jaa.1000064

Bellavite, P., and Donzelli, A. (2020). Hesperidin and SARS-CoV-2: New Light on the Healthy Function of Citrus Fruits. Antioxidants (Basel) 9, 742. doi:10.3390/ antiox9080742

Ben-Shabat, S., Yarmolinsky, L., Porat, D., and Dahan, A. (2020). Antiviral Effect of Phytochemicals from Medicinal Plants: Applications and Drug Delivery Strategies. Drug Deliv. Transl. Res. 10, 354-367. doi:10.1007/s13346-01900691-6

Benencia, F., and Courrèges, M. C. (2000). In Vitro andin Vivo Activity of Eugenol on Human Herpesvirus. Phytother. Res. 14, 495-500. doi:10.1002/10991573(200011)14:7<495:aid-ptr650>3.0.co;2-8

Bourjot, M., Leyssen, P., Eydoux, C., Guillemot, J. C., Canard, B., Rasoanaivo, P., et al. (2012). Flacourtosides A-F, Phenolic Glycosides Isolated from Flacourtia Ramontchi. J. Nat. Prod. 75, 752-758. doi:10.1021/np300059n

Caamal-Herrera, I., Muñoz-Rodríguez, D., Madera-Santana, T., and AzamarBarrios, J. (2016). Identification of Volatile Compounds in Essential Oil and Extracts of Ocimum Micranthum Willd Leaves Using GC/MS. Int. J. Appl. Res. Nat. Prod. 9, 31-40.

Cagno, V., Civra, A., Kumar, R., Pradhan, S., Donalisio, M., Sinha, B. N., et al. (2015). Ficus Religiosa L. Bark Extracts Inhibit Human Rhinovirus and Respiratory Syncytial Virus Infection In Vitro. J. Ethnopharmacol. 176, 252-257. doi:10.1016/j.jep.2015.10.042

Calabrese, C., Berman, S. H., Babish, J. G., Ma, X., Shinto, L., Dorr, M., et al. (2000). A Phase I Trial of Andrographolide in HIV Positive Patients and normal Volunteers. Phytother Res. 14, 333-338. doi:10.1002/1099-1573(200008)14: $5<333$ :aid-ptr584>3.0.co; 2 -d 
Chang, J. M., Huang, K. L., Yuan, T. T., Lai, Y. K., and Hung, L. M. (2010). The Anti-hepatitis B Virus Activity of Boehmeria Nivea Extract in HBV-Viremia SCID Mice. Evid. Based Complement. Alternat Med. 7, 189-195. doi:10.1093/ ecam $/$ nem 180

Chavan, R., and Chowdhary, A. (2014). In Vitro inhibitory Activity of Justicia Adhatoda Extracts against Influenza Virus Infection and Hemagglutination. Int. J. Pharm. Sci. Rev. Res. 25, 231-236. doi:10.1002/14651858

Chen, Y., and Zhu, J. (2013). Anti-HBV Effect of Individual Traditional Chinese Herbal Medicine In Vitro and In Vivo: an Analytic Review. J. Viral Hepat. 20, 445-452. doi:10.1111/jvh.12112

Cheng, Z., Sun, G., Guo, W., Huang, Y., Sun, W., Zhao, F., et al. (2015). Inhibition of Hepatitis B Virus Replication by Quercetin in Human Hepatoma Cell Lines. Virol. Sin 30, 261-268. doi:10.1007/s12250-015-3584-5

Choi, J. G., Lee, H., Kim, Y. S., Hwang, Y. H., Oh, Y. C., Lee, B., et al. (2019). Aloe Vera and its Components Inhibit Influenza A Virus-Induced Autophagy and Replication. Am. J. Chin. Med. 47, 1307-1324. doi:10.1142/ S0192415X19500678

Chou, S. C., Huang, T. J., Lin, E. H., Huang, C. H., and Chou, C. H. (2012). Antihepatitis B Virus Constituents of Solanum Erianthum. Nat. Prod. Commun. 7, 153-156. doi:10.1177/1934578x1200700205

Chung, Y. C., Hsieh, F. C., Lin, Y. J., Wu, T. Y., Lin, C. W., Lin, C. T., et al. (2015). Magnesium Lithospermate B and Rosmarinic Acid, Two Compounds Present in Salvia Miltiorrhiza, Have Potent Antiviral Activity against Enterovirus 71 Infections. Eur. J. Pharmacol. 755, 127-133. doi:10.1016/j.ejphar.2015.02.046

Dinangayi Tshilanda, D., Liyongo Inkoto, C., Mpongu, K., Mata, S., Kapepula Mutwale, P., Sha-Tshibey Tshibangu, D., et al. (2019). Microscopic Studies, Phytochemical and Biological Screenings of Ocimum Canum. Ijpc 5, 61-67. doi:10.11648/j.ijpc.20190505.13

El-Ansari, M. A., Ibrahim, L. F., and Sharaf, M. (2020). Anti-HIV Activity of Some Natural Phenolics. Herba Pol. 66, 34-43. doi:10.2478/hepo-2020-0010

Ghosh, M., Civra, A., Rittà, M., Cagno, V., Mavuduru, S. G., Awasthi, P., et al. (2016). Ficus Religiosa L. Bark Extracts Inhibit Infection by Herpes Simplex Virus Type 2 In Vitro. Arch. Virol. 161, 3509-3514. doi:10.1007/s00705-0163032-3

Ghosh, R., Chakraborty, A., Biswas, A., and Chowdhuri, S. (2021). Identification of Alkaloids from Justicia Adhatoda as Potent SARS CoV-2 Main Protease Inhibitors: An In Silico Perspective. J. Mol. Struct. 1229, 129489. doi:10.1016/j.molstruc.2020.129489

Gisondi, P., PIaserico, S., Bordin, C., Alaibac, M., Girolomoni, G., and Naldi, L. (2020). Cutaneous Manifestations of SARS-CoV-2 Infection: a Clinical Update. J. Eur. Acad. Dermatol. Venereol. 34, 2499-2504. doi:10.1111/jdv.16774

Gonçalves, J. L., Lopes, R. C., Oliveira, D. B., Costa, S. S., Miranda, M. M., Romanos, M. T., et al. (2005). In Vitro anti-rotavirus Activity of Some Medicinal Plants Used in Brazil against Diarrhea. J. Ethnopharmacol. 99, 403-407. doi:10.1016/ j.jep.2005.01.032

Goyal, R. K., Majeed, J., Tonk, R., Dhobi, M., Patel, B., Sharma, K., et al. (2020). Current Targets and Drug Candidates for Prevention and Treatment of SARSCoV-2 (COVID-19) Infection. Rev. Cardiovasc. Med. 21, 365-384. doi:10.31083/j.rcm.2020.03.118

Grimm, D., Thimme, R., and Blum, H. E. (2011). HBV Life Cycle and Novel Drug Targets. Hepatol. Int. 5, 644-653. doi:10.1007/s12072-011-9261-3

Haake, C., Cook, S., Pusterla, N., and Murphy, B. (2020). Coronavirus Infections in Companion Animals: Virology, Epidemiology, Clinical and Pathologic Features. Viruses 12, 1023. doi:10.3390/v12091023

Hafid, A. F., Aoki-Utsubo, C., Permanasari, A. A., Adianti, M., Tumewu, L., Widyawaruyanti, A., et al. (2017). Antiviral Activity of the Dichloromethane Extracts from Artocarpus Heterophyllus Leaves against Hepatitis C Virus. Asian Pac. J. Trop. Biomed. 7, 633-639. doi:10.1016/j.apjtb.2017.06.003

Heinrich, M., and Gibbons, S. (2001). Ethnopharmacology in Drug Discovery: an Analysis of its Role and Potential Contribution. J. Pharm. Pharmacol. 53, 425-432. doi:10.1211/0022357011775712

Henss, L., Auste, A., Schürmann, C., Schmidt, C., Von Rhein, C., Mühlebach, M. D., et al. (2021). The green tea Catechin Epigallocatechin Gallate Inhibits SARSCoV-2 Infection. J. Gen. Virol. 102, 001574. doi:10.1099/jgv.0.001574

Hussain, W., Haleem, K. S., Khan, I., Tauseef, I., Qayyum, S., Ahmed, B., et al. (2017). Medicinal Plants: a Repository of Antiviral Metabolites. Future Virol. 12, 299-308. doi:10.2217/fvl-2016-0110
Ikeda, K., Tsujimoto, K., Uozaki, M., Nishide, M., Suzuki, Y., Koyama, A. H., et al. (2011). Inhibition of Multiplication of Herpes Simplex Virus by Caffeic Acid. Int. J. Mol. Med. 28, 595-598. doi:10.3892/ijmm.2011.739

Jachak, S. M., and Saklani, A. (2007). Challenges and Opportunities in Drug Discovery from Plants. Curr. Sci. 92, 1251-1257. doi:10.1016/ j.jep.2006.12.031

Jayakumar, T., Hsieh, C. Y., Lee, J. J., and Sheu, J. R. (2013). Experimental and Clinical Pharmacology of Andrographis Paniculata and its Major Bioactive Phytoconstituent Andrographolide. Evid. Based Complement. Alternat Med. 2013, 846740. doi:10.1155/2013/846740

Jennings, M. R., and Parks, R. J. (2020). Curcumin as an Antiviral Agent. Viruses 12, 1242. doi:10.3390/v12111242

Jiang, Z. Y., Liu, W. F., Zhang, X. M., Luo, J., Ma, Y. B., and Chen, J. J. (2013). AntiHBV Active Constituents from Piper Longum. Bioorg. Med. Chem. Lett. 23, 2123-2127. doi:10.1016/j.bmcl.2013.01.118

Kaur, R., Sharma, P., Gupta, G. K., Ntie-Kang, F., and Kumar, D. (2020). StructureActivity-Relationship and Mechanistic Insights for Anti-HIV Natural Products. Molecules 25, 2070. doi:10.3390/molecules 25092070

Kaushik, S., Jangra, G., Kundu, V., Yadav, J. P., and Kaushik, S. (2020). Anti-viral Activity of Zingiber Officinale (Ginger) Ingredients against the Chikungunya Virus. VirusDisease 31, 1-7. doi:10.1007/s13337-020-00584-0

Kaushik-Basu, N., Bopda-Waffo, A., Talele, T. T., Basu, A., Costa, P. R., Da Silva, A. J., et al. (2008). Identification and Characterization of Coumestans as Novel HCV NS5B Polymerase Inhibitors. Nucleic Acids Res. 36, 1482-1496. doi:10.1093/nar/gkm1178

Khaerunnisa, S., Kurniawan, H., Awaluddin, R., Suhartati, S., and Soetjipto, S. (2020). Potential Inhibitor of COVID-19 Main Protease (Mpro) from Several Medicinal Plant Compounds by Molecular Docking Study. Preprints 2020, 1-14. doi:10.20944/preprints202003.0226.v1

Khanal, S., Ghimire, P., and Dhamoon, A. S. (2018). The Repertoire of Adenovirus in Human Disease: The Innocuous to the Deadly. Biomedicines 6, 30 . doi:10.3390/biomedicines6010030

Kim, H. J., Yoo, H. S., Kim, J. C., Park, C. S., Choi, M. S., Kim, M., et al. (2009). Antiviral Effect of Curcuma Longa Linn Extract against Hepatitis B Virus Replication. J. Ethnopharmacol. 124, 189-196. doi:10.1016/j.jep.2009.04.046

Kirchhoff, F. (2013). "HIV Life Cycle: Overview," in Encyclopedia of AIDS. Editors T. J. Hope, M. Stevenson, and D. Richman (New York City, NY: Springer), 1-9. doi:10.1007/978-1-4614-9610-6_60-1

Kubiça, T. F., Alves, S. H., Weiblen, R., and Lovato, L. T. (2014). In Vitro inhibition of the Bovine Viral Diarrhoea Virus by the Essential Oil of Ocimum Basilicum (Basil) and Monoterpenes. Braz. J. Microbiol. 45, 209-214. doi:10.1590/S151783822014005000030

Kurokawa, M., Shimizu, T., Watanabe, W., and Shiraki, K. (2010). Development of New Antiviral Agents from Natural Products. Open Antimicrob. Agents J. 2, 49. doi:10.2174/1876518101002020049

Lai, W. L., Chuang, H. S., Lee, M. H., Wei, C. L., Lin, C. F., and Tsai, Y. C. (2012). Inhibition of Herpes Simplex Virus Type 1 by Thymol-Related Monoterpenoids. Planta Med. 78, 1636-1638. doi:10.1055/s-0032-1315208

Li, S., Hattori, T., and Kodama, E. N. (2011). Epigallocatechin Gallate Inhibits the HIV Reverse Transcription Step. Antivir. Chem. Chemother. 21, 239-243. doi:10.3851/IMP1774

Lin, T. P., Chen, S. Y., Duh, P. D., Chang, L. K., and Liu, Y. N. (2008). Inhibition of the Epstein-Barr Virus Lytic Cycle by Andrographolide. Biol. Pharm. Bull. 31, 2018-2023. doi:10.1248/bpb.31.2018

Liu, X., Ma, C., Liu, Z., and Kang, W. (2020). Natural Products: Review for Their Effects of Anti-HBV. Biomed. Res. Int. 2020, 3972390. doi:10.1155/2020/ 3972390

Mamun, M. S. A. (2019). “Tea Production in Bangladesh: From Bush to Mug," in Agronomic Crops (Singapore: Springer), 441-505. doi:10.1007/978-981-329151-5_21

Manoharan, Y., Haridas, V., Vasanthakumar, K. C., Muthu, S., Thavoorullah, F. F., and Shetty, P. (2020). Curcumin: a Wonder Drug as a Preventive Measure for COVID19 Management. Indian J. Clin. Biochem. 35, 373-375. doi:10.1007/ s12291-020-00902-9

Maria Das Graças, B., Oliveira, J., Andrade, E. H. A., Trigo, J. R., Fonseca, R. C. M., and Rocha, A. E. S. (2007). Variation in Volatiles of Ocimum Campechianum Mill. And Ocimum Gratissimum L. Cultivated in the North of Brazil. J. Essent. Oil-Bearing Plants 10, 229. doi:10.1080/0972060X.2007.10643547 
Martin, K. W., and Ernst, E. (2003). Antiviral Agents from Plants and Herbs: a Systematic Review. Antivir. Ther. 8, 77-90. doi:10.1093/jac/dkg087

Mettenleiter, T. C., and Sobrino, F. (2008). Animal Viruses: Molecular Biology. Norfolk: Caister Academic Press.

Mpiana, P. T., Ngbolua, K. T., Tshibangu, D. S. T., Kilembe, J. T., Gbolo, B. Z., Mwanangombo, D. T., et al. (2020). Identification of Potential Inhibitors of SARS-CoV-2 Main Protease from Aloe Vera Compounds: A Molecular Docking Study. Chem. Phys. Lett. 754, 137751. doi:10.1016/j.cplett.2020.137751

Mukherjee, H., Ojha, D., Bag, P., Chandel, H. S., Bhattacharyya, S., Chatterjee, T. K., et al. (2013). Anti-herpes Virus Activities of Achyranthes aspera: an Indian Ethnomedicine, and its Triterpene Acid. Microbiol. Res. 168, 238-244. doi:10.1016/j.micres.2012.11.002

Nalanagula, M. (2020). Cynodon Dactylon against SARS-CoV-2 (COVID-19): Exploratory Considerations for Quick-Fix Pandemic Speed. Project: Cynodon dactylon against SARS-CoV-2 (COVID-19). doi:10.13140/RG.2.2.28950.98889

Nesari, T. M., Bhardwaj, A., Shrikrishna, R., Ruknuddin, G., Ghildiyal, S., Das, A., et al. (2021). Neem (Azadirachta Indica A. Juss) Capsules for Prophylaxis of COVID-19 Infection: A Pilot, Double-Blind, Randomized Controlled Trial. Altern. Ther. Health Med. 23, 1-8.

Nivetha, R., Bhuvaragavan, S., and Janarthanan, S. (2021). Inhibition of Multiple SARS-CoV-2 Roteins by An Antiviral Biomolecule, Seselin from Aeglemarmelos Deciphered Using Molecular Docking Analysis. Research Square. doi:10.21203/rs.3.rs-31134/v1

Palshetkar, A., Pathare, N., Jadhav, N., Pawar, M., Wadhwani, A., Kulkarni, S., et al. (2020). In Vitro anti-HIV Activity of Some Indian Medicinal Plant Extracts. BMC Complement. Med. Ther. 20, 69. doi:10.1186/s12906-020-2816-x

Panda, S. K., Padhi, L., Leyssen, P., Liu, M., Neyts, J., and Luyten, W. (2017). Antimicrobial, Anthelmintic, and Antiviral Activity of Plants Traditionally Used for Treating Infectious Disease in the Similipal Biosphere Reserve, Odisha, India. Front. Pharmacol. 8. doi:10.3389/fphar.2017.00658

Pandey, P., Singhal, D., Khan, F., and Arif, M. (2021). An In Silico Screening on Piper Nigrum, Syzygium Aromaticum and Zingiber Officinale roscoe Derived Compounds against Sars-cov-2: A Drug Repurposing Approach. Biointerface Res. Appl. Chem. 11. doi:10.33263/BRIAC114.1112211134

Pandey, S., Singh, S. K., Kumar, N., and Manjhi, R. (2017). Antiviral, Antiprotozoal, Antimalarial and Insecticidal Activities Ofocimum Gratissimum L. Asian J. Pharm. Res. Develop. 5, 1-9.

Panthong, P., Bunluepuech, K., Boonnak, N., Chaniad, P., Pianwanit, S., Wattanapiromsakul, C., et al. (2015). Anti-HIV-1 Integrase Activity and Molecular Docking of Compounds from Albizia Procera Bark. Pharm. Biol. 53, 1861-1866. doi:10.3109/13880209.2015.1014568

Parhira, S., Yang, Z. F., Zhu, G. Y., Chen, Q. L., Zhou, B. X., Wang, Y. T., et al. (2014). In Vitro Anti-Influenza Virus Activities of a New Lignan Glycoside from the Latex of Calotropis Gigantea. PLOS ONE 9, e104544. doi:10.1371/ journal.pone.0104544

Parvez, M. K., Al-Dosari, M. S., Alam, P., Rehman, M., Alajmi, M. F., and Alqahtani, A. S. (2019a). The Anti-hepatitis B Virus Therapeutic Potential of Anthraquinones Derived from Aloe Vera. Phytother Res. 33, 2960-2970. doi:10.1002/ptr.6471

Parvez, M. K., Al-Dosari, M. S., Arbab, A. H., Al-Rehaily, A. J., and Abdelwahid, M. A. S. (2020). Bioassay-guided Isolation of Anti-hepatitis B Virus Flavonoid Myricetin-3-O-Rhamnoside along with Quercetin from Guiera Senegalensis Leaves. Saudi Pharm. J. 28, 550-559. doi:10.1016/j.jsps.2020.03.006

Parvez, M. K., Arbab, A. H., Al-Dosari, M. S., and Al-Rehaily, A. J. (2016). Antiviral Natural Products against Chronic Hepatitis B: Recent Developments. Curr. Pharm. Des. 22, 286-293. doi:10.2174/1381612822666151112152733

Parvez, M. K., Tabish Rehman, M., Alam, P., Al-Dosari, M. S., Alqasoumi, S. I., and Alajmi, M. F. (2019b). Plant-derived Antiviral Drugs as Novel Hepatitis B Virus Inhibitors: Cell Culture and Molecular Docking Study. Saudi Pharm. J. 27, 389-400. doi:10.1016/j.jsps.2018.12.008

Perera, C., and Efferth, T. (2012). Antiviral Medicinal Herbs and Phytochemicals. J. Pharmacogn 3, 45-48. doi:10.9735/0976-884X.3.1.45-48

Phu, H. T., Thuan, D. T. B., Nguyen, T. H. D., Posadino, A. M., Eid, A. H., and Pintus, G. (2020). Herbal Medicine for Slowing Aging and Aging-Associated Conditions: Efficacy, Mechanisms and Safety. Curr. Vasc. Pharmacol. 18, 369-393. doi:10.2174/1570161117666190715121939

Pino Benitez, N., Meléndez León, E. M., and Stashenko, E. E. (2009). Eugenol and Methyl Eugenol Chemotypes of Essential Oil of Species Ocimum Gratissimum
L. And Ocimum Campechianum Mill. from Colombia. J. Chromatogr. Sci. 47, 800-803. doi:10.1093/chromsci/47.9.800

Pirzada, A. M., Ali, H. H., Naeem, M., Latif, M., Bukhari, A. H., and Tanveer, A. (2015). Cyperus Rotundus L.: Traditional Uses, Phytochemistry, and Pharmacological Activities. J. Ethnopharmacol. 174, 540-560. doi:10.1016/ j.jep.2015.08.012

Priya, N., and Saravana Kumari, P. (2017). Antiviral Activities and Cytotoxicity Assay of Seed Extracts of Piper Longum and Piper Nigrum on Human Cell Lines. Int. J. Pharm. Sci. Rev. Res. 44, 197-202.

Qiu, L. P., and Chen, K. P. (2013). Anti-HBV Agents Derived from Botanical Origin. Fitoterapia 84, 140-157. doi:10.1016/j.fitote.2012.11.003

Rao, V. B., and Yeturu, K. (2020). Possible Anti-viral Effects of Neem (Azadirachta indica) on Dengue Virus. bioRxiv 2020. doi:10.1101/2020.04.29.069567

Rathinavel, T., Palanisamy, M., Srinivasan, P., Subramanian, A., and Thangaswamy, S. (2020). Phytochemical 6-Gingerol -A Promising Drug of Choice for COVID-19. Int. J. Adv. Sci. Eng. 06, 1482. doi:10.29294/ ijase.6.4.2020.1482-1489

Ren, Y., Shu, T., Wu, D., Mu, J., Wang, C., Huang, M., et al. (2020). The ORF3a Protein of SARS-CoV-2 Induces Apoptosis in Cells. Cell Mol. Immunol 17, 881-883. doi:10.1038/s41423-020-0485-9

Rezazadeh, F., Moshaverinia, M., Motamedifar, M., and Alyaseri, M. (2016). Assessment of Anti HSV-1 Activity of Aloe Vera Gel Extract: an In Vitro Study. J. Dent (Shiraz) 17, 49-54.

Romeilah, R. M., Fayed, S. A., and Mahmoud, G. I. (2010). Chemical Compositions, Antiviral and Antioxidant Activities of Seven Essential Oils. J. Appl. Sci. Res. 6, 50-62. doi:10.3923/ajb.2016.104.117

Rouf, R., Uddin, S. J., Sarker, D. K., Islam, M. T., Ali, E. S., Shilpi, J. A., et al. (2020). Antiviral Potential of Garlic (Allium Sativum) and its Organosulfur Compounds: A Systematic Update of Pre-clinical and Clinical Data. Trends Food Sci. Technol. 104, 219-234. doi:10.1016/j.tifs.2020.08.006

Samra, R. M., Soliman, A. F., Zaki, A. A., El-Gendy, A. N., Hassan, M. A., and Zaghloul, A. M. (2020). Chemical Composition, Antiviral and Cytotoxic Activities of Essential Oil from Cyperus Rotundus Growing in Egypt: Evidence from Chemometrics Analysis. J. Essent. Oil Bearing Plants 23, 648-659. doi:10.1080/0972060x.2020.1823892

Schwarz, S., Sauter, D., Wang, K., Zhang, R., Sun, B., Karioti, A., et al. (2014). Kaempferol Derivatives as Antiviral Drugs against the 3a Channel Protein of Coronavirus. Planta Med. 80, 177-182. doi:10.1055/s-0033-1360277

Silva, M. G., Vieira, I. G., Mendes, F. N., Albuquerque, I. L., Dos Santos, R. N., Silva, F. O., et al. (2008). Variation of Ursolic Acid Content in Eight Ocimum Species from Northeastern Brazil. Molecules 13, 2482-2487. doi:10.3390/ molecules 13102482

Sivakrishnan, S., and Swamivelmanickam, M. (2019). A Comprehensive Review of Albizia Procera (Roxb.) Benth.-An Update. doi:10.7897/2230-8407.1006193

Solnier, J., and Fladerer, J.-P. (2020). Flavonoids: A Complementary Approach to Conventional Therapy of COVID-19? Phytochem. Rev., 1-23. doi:10.1007/ s11101-020-09720-6

Straface, G., Selmin, A., Zanardo, V., De Santis, M., Ercoli, A., and Scambia, G. (2012). Herpes Simplex Virus Infection in Pregnancy. Infect. Dis. Obstet. Gynecol. 2012, 385697. doi:10.1155/2012/385697

Tan, W. C., Jaganath, I. B., Manikam, R., and Sekaran, S. D. (2013). Evaluation of Antiviral Activities of Four Local Malaysian Phyllanthus Species against Herpes Simplex Viruses and Possible Antiviral Target. Int. J. Med. Sci. 10, 1817-1829. doi:10.7150/ijms.6902

Thimmulappa, R. K., Mudnakudu-Nagaraju, K. K., Shivamallu, C., Subramaniam, K. J. T., Radhakrishnan, A., Bhojraj, S., et al. (2021). Antiviral and Immunomodulatory Activity of Curcumin: A Case for Prophylactic Therapy for COVID-19. Heliyon 7, e06350. doi:10.1016/j.heliyon.2021.e06350

Tiwari, P., Jena, S., and Sahu, P. (2019). Butea Monosperma: Phytochemistry and Pharmacology. Acta Scietific Pharmaceutical Science 3 (4), 19-26.

Tshilanda, D. D., Ngoyi, E. M., Kabengele, C. N., Matondo, A., Bongo, G. N., Inkoto, C. L., et al. (2020). Ocimum Species as Potential Bioresources against COVID-19: A Review of Their Phytochemistry and Antiviral Activity. Ijpr, 42-54. doi:10.9734/ijpr/2020/v5i430143

Verma, H., Patil, P. R., Kolhapure, R. M., and Gopalkrishna, V. (2008). Antiviral Activity of the Indian Medicinal Plant Extract Swertia Chirata against Herpes Simplex Viruses: a Study by Iin-Vvitro and Molecular Approach. Indian J. Med. Microbiol. 26, 322-326. doi:10.1016/s0255-0857(21)01807-7 
V'kovski, P., Kratzel, A., Steiner, S., Stalder, H., and Thiel, V. (2021). Coronavirus Biology and Replication: Implications for SARS-CoV-2. Nat. Rev. Microbiol. 19, 155-170. doi:10.1038/s41579-020-00468-6

Wahyuni, T., Azmi, D., Permanasari, A., Adianti, M., Tumewu, L., Widiandani, T., et al. (2019). ANTI-VIRAL ACTIVITY of Phyllanthus Niruri against HEPATITIS C VIRUS. Malaysian Appl. Biol. 48, 105-111.

Wang, D., Guo, H., Chang, J., Wang, D., Liu, B., Gao, P., et al. (2018). Andrographolide Prevents EV-D68 Replication by Inhibiting the Acidification of Virus-Containing Endocytic Vesicles. Front. Microbiol. 9, 2407. doi:10.3389/fmicb.2018.02407

Wang, G. C., Li, T., Deng, F. Y., Li, Y. L., and Ye, W. C. (2013). Five New Phenolic Glycosides from Hedyotis Scandens. Bioorg. Med. Chem. Lett. 23, 1379-1382. doi:10.1016/j.bmcl.2012.12.077

Wang, L., Jiao, H., Zhao, J., Wang, X., Sun, S., and Lin, H. (2017). Allicin Alleviates Reticuloendotheliosis Virus-Induced Immunosuppression via ERK/mitogenactivated Protein Kinase Pathway in Specific Pathogen-free Chickens. Front. Immunol. 8, 1856. doi:10.3389/fimmu.2017.01856

Wei, P. H., Wu, S. Z., Mu, X. M., Xu, B., Su, Q. J., Wei, J. L., et al. (2015). Effect of Alcohol Extract of Acanthus ilicifolius L. On Anti-duck Hepatitis B Virus and protection of Liver. J. Ethnopharmacol. 160, 1-5. doi:10.1016/ j.jep.2014.10.050

Wiart, C., Kumar, K., Yusof, M. Y., Hamimah, H., Fauzi, Z. M., and Sulaiman, M. (2005). Antiviral Properties of Ent-Labdene Diterpenes of Andrographis Paniculata Nees, Inhibitors of Herpes Simplex Virus Type 1. Phytother Res. 19, 1069-1070. doi:10.1002/ptr.1765

Williamson, M. P., Mccormick, T. G., Nance, C. L., and Shearer, W. T. (2006). Epigallocatechin Gallate, the Main Polyphenol in green tea, Binds to the T-Cell Receptor, CD4: Potential for HIV-1 Therapy. J. Allergy Clin. Immunol. 118, 1369-1374. doi:10.1016/j.jaci.2006.08.016

Wu, Y. H. (2016). Naturally Derived Anti-hepatitis B Virus Agents and Their Mechanism of Action. World J. Gastroenterol. 22, 188-204. doi:10.3748/wjg.v22.i1.188

$\mathrm{Xu}$, J., Xu, Z., and Zheng, W. (2017). A Review of the Antiviral Role of Green Tea Catechins. Molecules 22, 1337. doi:10.3390/molecules22081337

Yang, Z., Wu, N., Fu, Y., Yang, G., Wang, W., Zu, Y., et al. (2010). Anti-infectious Bronchitis Virus (IBV) Activity of 1,8-cineole: Effect on Nucleocapsid (N) Protein. J. Biomol. Struct. Dyn. 28, 323-330. doi:10.1080/07391102.2010.10507362
Zhang, H. S., Wu, T. C., Sang, W. W., and Ruan, Z. (2012). EGCG Inhibits TatInduced LTR Transactivation: Role of Nrf2, AKT, AMPK Signaling Pathway. Life Sci. 90, 747-754. doi:10.1016/j.lfs.2012.03.013

Zhang, Y. B., Wu, P., Zhang, X. L., Xia, C., Li, G. Q., Ye, W. C., et al. (2015). Phenolic Compounds from the Flowers of Bombax Malabaricum and Their Antioxidant and Antiviral Activities. Molecules 20, 19947-19957. doi:10.3390/molecules201119660

Zhang, Y. B., Zhang, X. L., Chen, N. H., Wu, Z. N., Ye, W. C., Li, Y. L., et al. (2017). Four Matrine-Based Alkaloids with Antiviral Activities against HBV from the Seeds of Sophora Alopecuroides. Org. Lett. 19, 424-427. doi:10.1021/ acs.orglett.6b03685

Zhou, H. X., Li, R. F., Wang, Y. F., Shen, L. H., Cai, L. H., Weng, Y. C., et al. (2020). Total Alkaloids from Alstonia scholaris Inhibit Influenza a Virus Replication and Lung Immunopathology by Regulating the Innate Immune Response. Phytomedicine 77, 153272. doi:10.1016/ j.phymed.2020.153272

Zhou, N. J., Geng, C. A., Huang, X. Y., Ma, Y. B., Zhang, X. M., Wang, J. L., et al. (2015). Anti-hepatitis B Virus Active Constituents from Swertia Chirayita. Fitoterapia 100, 27-34. doi:10.1016/j.fitote.2014.11.011

Conflict of Interest: The authors declare that the research was conducted in the absence of any commercial or financial relationships that could be construed as a potential conflict of interest.

Publisher's Note: All claims expressed in this article are solely those of the authors and do not necessarily represent those of their affiliated organizations, or those of the publisher, the editors and the reviewers. Any product that may be evaluated in this article, or claim that may be made by its manufacturer, is not guaranteed or endorsed by the publisher.

Copyright (c) 2021 Bachar, Mazumder, Bachar, Aktar and Al Mahtab. This is an open-access article distributed under the terms of the Creative Commons Attribution License (CC BY). The use, distribution or reproduction in other forums is permitted, provided the original author(s) and the copyright owner(s) are credited and that the original publication in this journal is cited, in accordance with accepted academic practice. No use, distribution or reproduction is permitted which does not comply with these terms. 